\title{
Totalitarismo empresarial: uma análise do sistema Bata no Brasil e no Chile $(1940-1970)$
}

\author{
Corporate totalitarianism: an analysis of Bata system in Brazil \\ and Chile (1940-1970)
}

\section{Vinícius de Rezende*}

Resumo: A partir dos anos 1930, a Bata Shoes Corporation, empresa de origem checa, se consolidou como uma organização multinacional que figurou entre os maiores produtores mundiais de calçados e foi precursora na realização de transformações de ordem econômica, organizacional e social nas suas instalações em mais de 40 países. Além da racionalização dos processos produtivos, fundou escolas industriais para formar seus dirigentes industriais e notabilizou-se por construir vilas operárias dotadas de aparatos assistenciais para os seus funcionários. Neste artigo, analiso como se deu a implantação do sistema Bata - conjunto de métodos de produção e de técnicas de gestão - no Brasil e no Chile, entre as décadas de 1940 e 1970, tendo como principal objetivo interpretar as características do projeto de controle social que buscava exercer um domínio praticamente total sobre os trabalhadores, indo além dos espaços e dos tempos de trabalho, ao adentrar as esferas domésticas e os períodos de ócio.

Palavras-chave: Sistema Bata; controle social; totalitarismo empresarial.

Abstract: During the 1930s, the Czech company Bata Shoes Corporation became a wellestablished multinational organization. It figured amidst the largest shoes producers in the world, being a pioneer in carrying out economic, organizational and social transformations in its internationally widespread facilities. In addition to the improvement of production processes, Bata Shoes Corporation managed to create industrial schools in different countries to train its industrial managers. The company was also recognized for providing workers with habitation

* Doutor em História Social e Pós-doutorado em Sociologia do Trabalho pela Universidade Estadual de Campinas (Unicamp); Professor do Departamento de História e do Programa de Pós-Graduação em História da Universidade Federal da Bahia (UFBA). ORCID: https://orcid.org/0000-0002-1941-6458. E-mail: vdrezende@ yahoo.com.br. 
located in company towns. In this article, I analyse how production methods and management techniques created by Bata (the Bata System) were implemented in Brazil and Chile, between the 1940s and 1970s. The paper's main objective is to analyse the characteristics of a project which ultimately sought to expand the corporation's control over its workers. I argue that Bata exerted a huge dominance over its employees, specially through pervasive practices related not only to factory dynamics, but also to labourer's private lives.

Keywords: Bata system; social control; corporate totalitarianism.

\section{O totalitarismo empresarial}

0 PRESENTE ARTIGO APRESENTA parte dos resultados de uma pesquisa mais ampla, em desenvolvimento, dedicada a analisar como se deu a efetivação do sistema Bata - conjunto de métodos de produção e de técnicas de gestão - e sua apropriação pelos trabalhadores em diferentes conjunturas espaciais e temporais entre os anos 1940 e 2000, sendo o marco inicial a transferência da sede administrativa da organização mundial para o continente americano e a baliza final o processo de reestruturação que levou ao fechamento de unidades produtivas em vários países e à concentração da produção na Ásia. Por meio de um amplo estudo comparativo, de perspectivas transnacionais, objetivo interpretar as principais características das fábricas e das vilas operárias edificadas no Brasil, no Canadá e no Chile, assim como, as organizações e os movimentos operários nesses países.

Os princípios administrativos, disciplinares e organizacionais da Bata tinham como meta serem transpostos para diferentes países, passando por cima das singularidades e das fronteiras nacionais. Por isso, os atuais estudos que adotam a perspectiva da "História Global do Trabalho" têm me auxiliado na fundamentação teórico-metodológica para pesquisar a história dessa empresa multinacional e de seus trabalhadores. Segundo Marcel van der Linden, uma das premissas da "História Global" é sua tentativa de superar o nacionalismo metodológico e o eurocentrismo e, entre seus temas, "focaliza o estudo transnacional e mesmo transcontinental das relações de trabalho e dos movimentos sociais de trabalhadores no sentido mais amplo da palavra. Por 'transnacional', quero dizer, situar, no contexto mais amplo de todos os processos históricos". ${ }^{1}$

No transcorrer do texto, restringirei a exposição à interpretação das características e dos principais significados da implementação do projeto de controle social nas unidades produtivas e nas comunidades operárias erigidas no Brasil (Batatuba-SP) e no Chile (Peñaflor) entre os anos 1940 e $1970,{ }^{2}$ tendo como principais fontes as publicações internas da organização e os

1 LINDEN, Marcel van der. História do Trabalho: o velho, o novo e o global. Revista Mundos do Trabalho, v. 1, n. 1, 2009, p. 18.

2 No Brasil, Jan Bata faleceu em 1965; seu filho assumiu a direção da empresa, mas faleceu precocemente e a SAPACO entrou alguns anos depois em falência e encerrou suas atividades em 1983. No Chile, a Bata sofreu forte concorrência dos calçados asiáticos a partir da abertura do mercado pelo governo de Augusto 
relatos orais de ex-trabalhadores e de ex-gestores chilenos. A partir desse recorte temático e devido às limitações de espaço, optei por não abordar os aspectos diretamente relacionados aos aperfeiçoamentos e às transformações dos processos produtivos, que devido às suas complexidades serão objetos de um artigo específico. Não obstante, é importante ressaltar que essa opção não interfere significativamente nos resultados a respeito da análise das estratégias de controle social, visto que as transformações dos processos produtivos e a disciplinarização da força de trabalho se complementaram e visaram, em última instância, auferir ganhos de produtividade sempre crescentes e promover o ideal de harmonia social entre trabalho e capital.

Ao iniciar a pesquisa sobre o sistema Bata e as ações dos trabalhadores, mobilizei dois conceitos para fundamentar a análise de temas como a harmonia e a minimização de conflitos sociais, a prestação de serviços assistenciais aos trabalhadores e a construção das vilas operárias: paternalismo industrial e capitalismo de bem-estar. ${ }^{3}$ Segundo E. P. Thompson, a constituição do sistema fabril acarretou a alteração da natureza e da intensidade da exploração econômica e da opressão política, visto que "as relações entre patrões e empregados tornaram-se mais duras e menos pessoais". Todavia, o autor advertiu que "nenhum empreendimento industrial complexo poderia ser conduzido [exclusivamente] de acordo com essa filosofia" e que "a necessidade de paz na indústria, de uma força de trabalho estável e de um corpo de trabalhadores capacitados e experientes exigia a modificação das técnicas gerenciais" e a elaboração de "novas formas de paternalismo". ${ }^{4}$ Em outro texto, o autor indicou que o termo paternalismo era usualmente empregado para explicar realidades históricas extremamente díspares. ${ }^{5}$ Para meus propósitos, importa sua utilização para interpretar determinadas características das relações de trabalho na sociedade industrial: as ações empresariais de prestação de serviços aos funcionários com o propósito de atrair e fixar a força de trabalho, discipliná-la (moldá-la), minimizar e, se possível, evitar as ações autônomas dos trabalhadores e a eclosão de conflitos de classes.

Nesse sentido, ao analisar as transformações da estrutura disciplinar das indústrias francesas, Perrot definiu o paternalismo como um sistema de administração industrial, predominante no século XVIII e persistente no XIX, composto por três elementos: a presença física do patrão no chão de fábrica; a concepção das relações de trabalho segundo "o modelo familiar: na linguagem da empresa familiar o patrão é o pai, e os operários os filhos"; e a

Pinochet e encerrou as atividades produtivas no país na primeira década do século XXI, como resultado da reestruturação global da organização.

3 A diferenciação que eu estabeleço entre os dois conceitos não é consensual na historiografia a respeito do tema, e alguns autores os consideram equivalentes. Entre outros, ALVAREZ, José Sierra. El obrero soñado. Ensayo sobre el paternalismo industrial (Asturias, 1860-1917). Madri: Siglo XXI, 1990; e VERGARA. Ángela. Paternalismo industrial, empresa extranjera y campamentos mineros en América Latina: un esfuerzo de historia laboral y transnacional. Avances del Cesor, Año X, n. 10, p. 113-128, 2013.

4 THOMPSON, E. P. A formação da classe operária inglesa. v. 2. Rio de Janeiro: Paz e Terra, 1987, p. $23,28$. (grifos meus)

5 Para uma crítica à imprecisão do termo paternalismo: Idem. La sociedad inglesa del siglo XVIII: ¿Lucha de clases sin clases? In: Tradición, revuelta y consciencia de clase. Estudios sobre la crises de la sociedad preindustrial. $2^{\mathrm{a}}$ ed. Barcelona: Editorial Crítica, 1984, p. 13-61. 
aceitação, quando não a reivindicação, por parte dos trabalhadores desse tipo de integração, "têm orgulho em pertencer à empresa com a qual se identificam." Uma interpretação mais rigorosa desta definição restringiria seu emprego às indústrias dos primórdios do desenvolvimento industrial, em especial, às fábricas em que o proprietário era o principal, quando não, o único responsável pela fiscalização direta do trabalho.

Porém, a proximidade entre patrões e empregados e principalmente a metáfora do "pai-patrão" não se restringiram aos primórdios do sistema fabril, ${ }^{7}$ o que estimula diferentes autores a interpretar a persistência das relações paternalistas nas empresas em que a administração direta da força de trabalho era realizada por gestores. ${ }^{8}$ Dessa maneira, o conceito de paternalismo industrial contribui para se analisar as práticas de indústrias de grande porte, no século $X X$, que concederam benefícios e serviços aos seus funcionários e difundiram a concepção de constituírem "grandes famílias" industriais. ${ }^{9}$

A meu ver, o termo paternalismo industrial possui grande serventia e, muitas vezes, o utilizei para explicar determinadas relações sociais predominantes em algumas indústrias do setor coureiro-calçadista de Franca-SP. Não obstante, compreendo que o emprego do conceito deve ser bem contextualizado, visto que utilizá-lo de forma indistinta oferece o risco de se definir sob a mesma terminologia realidades significativamente distintas. Demonstrei em Vidas Fabris ${ }^{10}$ que nas indústrias de calçados e de couros de pequeno e de médio porte predominaram as relações sociais informais e pessoalizadas. Naqueles casos, inexistia uma política social voltada aos trabalhadores, e as concessões feitas pelos empregadores eram pontuais e espontâneas, muitas vezes interpretadas pelos recebedores como obras da benevolência dos patrões. De forma distinta, em algumas empresas de grande porte ocorreu a profissionalização da assistência aos trabalhadores e as ações deixaram de ser atos informais e pessoais desse ou daquele industrial, compondo um conjunto de serviços administrados pelos departamentos de pessoal, de serviço social ou de recursos humanos.

O estabelecimento de políticas sociais geridas por departamentos especializados nem sempre prescindiu da utilização da figura do proprietário fundador como benfeitor. Nos EUA, a indústria de calçados Endicott Johnson Corporation, por exemplo, desenvolveu um

6 PERROT, Michelle. Os excluídos da história: operários, mulheres e prisioneiros. Rio de Janeiro: Paz e Terra, 1988, p. 61-62.

7 Nas primeiras décadas do século $X X$, essa realidade estava difundida em vários segmentos produtivos do Brasil. Cf. PINHEIRO, Paulo S; HALL, Michael M. A classe operária no Brasil. Condições de vida e de trabalho, relações com os empresários e o Estado. v. II. São Paulo: Brasiliense, 1981, p. 174-175, 208.

8 Cf. REID, Donald. Industrial Paternalism: discourse and practice in Nineteenth-Century French mining and Metallurgy. Comparative Studies in Society and History, v. 27, n. 4, p. 579-607, 1985.

9 A bibliografia nacional e internacional sobre o tema é bastante vasta. Dentre outros, cf. Le Mouvement social, n. 144, Paternalismes d'Hier et d'Aujourd'hui., p. 1-134, jul.-sep., 1988; FONTES, Paulo. Trabalhadores e cidadãos: Nitro Química: a fábrica e as lutas operárias nos anos 50. São Paulo: Annablume, 1997; FORTES, Alexandre. Nós do quarto distrito: a classe trabalhadora porto-alegrense e a Era Vargas. Caxias do Sul, RS/ Rio de Janeiro: Educs/Garamond, 2004; LOPES, José S. L. A tecelagem dos conflitos de classe na "cidade das chaminés". São Paulo/Brasília: Marco Zero/Ed. UnB, 1988; WEID, Elisabeth von der. O fio da meada: estratégia de expansão de uma indústria têxtil. Companhia América Fabril, 1878-1930. Rio de Janeiro: FCRBCNI, 1986.

10 REZENDE, Vinícius de. Vidas fabris: trabalho e conflito social no complexo coureiro-calçadista de Franca-SP (1950-1980). São Paulo: Alameda, 2017. 
abrangente sistema assistencial durante as primeiras décadas do século $\mathrm{XX}$, construído sobre práticas paternalistas que datavam de 1890, associando-o deliberadamente à figura de G. F. Johnson como pai. ${ }^{11}$ Esta empresa foi uma das principais fontes de inspiração para Tomas Bata desenvolver a política social de suas indústrias em Zlín, na Checoslováquia, pois, de acordo com Cekota, a ampla rede assistencial da Endicott Johnson o deixou tão impressionado quanto a infraestrutura produtiva da Ford. ${ }^{12}$

A política assistencial posta em prática por aquela indústria calçadista estadunidense compôs um processo mais amplo em que diferentes empresas assumiram maiores responsabilidades sobre o bem-estar de seus empregados e forjaram um movimento que ficou conhecido como welfare capitalism ou welfare work. Consistiu na implantação de uma série de reformas sociais com o objetivo de diminuir os conflitos de trabalho, melhorar a moral do trabalhador e cultivar sua lealdade. ${ }^{13}$ De tal modo, ainda que o capitalismo de bem-estar possa ser interpretado como um aperfeiçoamento, ou mesmo um desdobramento do paternalismo industrial, tenho diferenciado os dois termos e considerado o primeiro mais profícuo para se interpretar os casos em que as políticas assistenciais das grandes empresas foram profissionalizadas, mesmo que nem todas deixassem de usar a metáfora do "pai-patrão". Além disso, em pesquisa anterior constatei que a referida profissionalização contribuiu para que muitos trabalhadores substituíssem a antiga metáfora por outra que mantinha a concepção de "família industrial", mas tendia a refletir a impessoalidade da prestação de serviços: a "empresa-mãe". ${ }^{14}$

Assim, ao pesquisar a difusão do sistema Bata nas Américas, considerei que o conceito de capitalismo de bem-estar (ou assistencialismo industrial) - entendido como a profissionalização da prestação de serviços aos funcionários - poderia ser empregado para interpretar o objeto da pesquisa. Não obstante, estive atento à relevância de considerar a provável influência da presença física dos proprietários - Jan Bata no Brasil e Thomas Bata no Canadá e no Chile - sobre seus funcionários, visto que a imagem de ambos como "pais-patrões", ou como benfeitores, poderia ter sido estrategicamente difundida e reforçada para fins de controle social.

Com o avançar da análise de fontes, verifiquei que o domínio social da Bata se estendeu para os tempos de ócio de seus funcionários e, consequentemente, para a esfera privada das

11 Cf. ZAHAVI, Gerald. Negotiated Loyalty: welfare capitalism and the shoeworkers of Endicott Johnson, $1920-$ 1940. The Journal of American History, v. 70, n. 3, p. 602-620, dec. 1983. No Brasil, as indústrias Renner exemplificaram a construção do capitalismo social associado à imagem de um "pai severo e atencioso". Cf. FORTES, op. cit., p. 204-207. A respeito das tensões envolvidas na transição da administração paternalista para a construção de um aparato assistencial profissionalizado, cf. LOPES, op. cit., p. 180-183.

12 Cf. CEKOTA, Anthony. Entrepreneur extraordinary. The biography of Tomas Bata. Rome/Italy: EIS; Ontario/ CA: T.H. Best Printing Co., 1968, p. 149-150.

13 Cf. entre outros, BRANDES, Stuart D. American Welfare Capitalism, 1880-1940. Chicago: The Univ. of Chicago Press, 1976; BRODY, David. The rise and decline of welfare capitalism. In: Workers in Industrial America: essays on the twentieth century struggle. New York: Oxford Univ. Press, 1980, p. 48-81; e NELSON, Daniel. Managers and Workers. Origins of the new factory system in the United States. 1820-1920. Madison, Wisconsin: The University of Wisconsin Press, 1975, p. 101-121.

14 REZENDE, op. cit., p. 314. 
suas vidas: para os espaços de produção e de reprodução da força de trabalho; e constatei que o discurso reproduzido nas publicações empresariais destinadas aos trabalhadores e aos seus familiares estimulava o desenvolvimento de um sentimento de pertencimento a uma empresa global. Por isso, considerei que o conceito de Estado Amplo tal como formulado por João Bernardo poderia ser vantajoso para interpretar os significados mais amplos do sistema Bata, ao tomá-lo como um exemplo do exercício da soberania das empresas, que exercem poderes semelhantes aos do Estado clássico (Estado Restrito) - administrar, legislar e julgar - mas de forma mais difusa e para além das fronteiras territoriais do Estado nação. ${ }^{15}$

A principal consequência de incorporar essa perspectiva teórica foi considerar que para além do paternalismo industrial e do capitalismo de bem-estar, o domínio econômico, político, cultural e social da Bata poderia ser mais bem compreendido como um caso de totalitarismo empresarial, definido como um modelo de dominação que tinha a finalidade de alcançar um controle total sobre os trabalhadores e seus familiares e que se fundamentava no ideal de harmonia social e na constituição de um coletivo plenamente identificado com os interesses e os ideais da organização. ${ }^{16}$ Além disso, a dominação total foi concebida numa perspectiva transnacional, uma vez que seus princípios administrativos, disciplinares e organizacionais objetivavam possibilitar a transposição do sistema Bata para qualquer país.

\section{"O dia tem 86.400 segundos": os fundamentos do sistema Bata}

A PEQUENA EMPRESA FUNDADA POR TOMAS BATA, em 1894, na cidade de Zlín, desenvolveu-se significativamente no transcurso das primeiras décadas do século $X X$ e, a partir de um processo de expansão dos negócios intensificado nos anos 1930, tornou-se uma organização multinacional que se destacou entre as maiores produtoras mundiais de calçados, com unidades produtivas e cadeias de lojas instaladas em mais de 40 países na Europa, na América, na África e na Ásia. A Bata Shoes Corporation foi precursora na realização de transformações de ordem econômica e organizacional: construiu maquinário, aperfeiçoou tecnologias e difundiu métodos de gerenciamento para o setor coureiro-calçadista como um todo, em consonância com as principais transformações dos meios de produção e da gestão das relações de trabalho ao longo do século XX.

15 Cf. BERNARDO, João. Economia dos conflitos sociais. $2^{a}$ ed. São Paulo: Expressão Popular, 2009 ; Idem. Democracia totalitária: teoria e prática da empresa soberana. São Paulo: Cortez, 2004.

16 Outra inspiração para a definição de totalitarismo empresarial, tal como proponho, foi Harry Braverman, que ao analisar as "origens da gerência" apontou que, por meio do fornecimento de benefícios variados, algumas fábricas forjaram um "completo sistema social que abrangia jurisdições inteiras. [...] Neste método de total dominação econômica, espiritual, moral e física", em áreas espacialmente segregadas, se encontraria o precursor das company towns estadunidenses do século XX. BRAVERMAN, Harry. Trabalho e capital monopolista: a degradação do trabalho no século XX. $3^{\text {a }}$ ed. Rio de Janeiro: Zahar, 1980, p. 67.

Entre aqueles que utilizam o conceito de paternalismo industrial, é possível encontrar expressões como "instituição total" e "controle totalizador" para se interpretar as práticas paternalistas. Respectivamente, ALVAREZ, op. cit.; e VENEGAS VALDEBENITO, Hernán; MORALES BARRIENTOS, Diego. Um caso de paternalismo industrial en Tomé: familia, espacio urbano y sociabilidad de los obreros textiles (1920-1940). HISTORIA, n. 50, v. I, p. 273-302, 2017. 
Entre as alterações dos processos produtivos com o intuito de retirar o controle do ritmo e da cadência de trabalho das mãos dos trabalhadores, aumentar a produtividade e intensificar a extração de mais-valia, a Bata foi pioneira na instalação das linhas de montagem na fabricação de calçados. Entre as várias viagens que Tomas Bata realizou ao exterior, em 1919, ele foi aos Estados Unidos e visitou a fábrica de automóveis de Henry Ford em Detroit, onde viu em funcionamento as linhas de montagem. ${ }^{17}$ A partir dessa inspiração, em 1927, foram instaladas esteiras transportadoras nas seções de costura, de montagem e de acabamento de calçados da Bata em Zlín. A inovação fez parte de um processo mais amplo de reorganização do trabalho que englobou a planificação da produção e um sistema gerencial de "autonomia das oficinas" considerado bastante avançado para a época. ${ }^{18} \mathrm{~A}$ produção diária de calçados passou de 8.000 pares em 1923 para 75.000 pares em 1928 e atingiu 168.000 pares em $1935 .{ }^{19}$

Outra realização de destaque da empresa foi a fundação, em 1924, da Bata School of Labor em Zlín. A escola foi fundada com o objetivo de formar os futuros dirigentes industriais da organização. Tomas Bata idealizou um sistema educacional que combinava a educação teórica com assuntos técnicos e comerciais no local de trabalho. Os jovens trabalhavam durante o dia e tinham aulas no período noturno, e o principal objetivo era, após três anos de internato, formar profissionais com engenhosidade e iniciativa. ${ }^{20} \mathrm{Em}$ pesquisa, realizada no final dos anos 1920, o International Labour Office destacou que o sistema de ensino e trabalho fundamentava-se numa disciplina militar, com normas de conduta rígidas, que determinavam a possibilidade de os internos serem demitidos a qualquer momento caso as desrespeitassem. Os jovens iniciavam suas atividades às 5:30 com exercícios físicos, trabalhavam na fábrica entre 7:00 e 12:00 e 14:00 e 17:00, assistiam aulas entre 18:00 e 20:00 e deitavam-se às 21:00. Seguiam essa rotina de segunda a sábado. ${ }^{21}$

Os candidatos a uma vaga na Bata School of Labor passavam por um rigoroso processo de seleção e tinham aulas de economia, contabilidade, correspondência comercial, inglês, alemão, desenho, desenvolvimento de calçados, entre outras disciplinas, de acordo com suas aptidões. ${ }^{22}$ Nos anos subsequentes, a jornada de trabalho dos alunos foi reduzida para meio

17 Conforme afirmei anteriormente, Anthony Cekota apontou a indústria calçadista Endicott Johnson Corporation como uma das principais fontes de inspiração para Tomas Bata implementar uma política social em Zlín. Não obstante, é oportuno aventar que as influências da Ford podem ter ido além da racionalização da produção, pois a empresa teve grande destaque na concepção e efetivação de políticas sociais destinadas a resolver os "problemas humanos" e forjar o "novo operário". O marco mais famoso dessas ações foi o estabelecimento, em 1914, do "five dollar day", que resultou na criação do Departamento Sociológico destinado a moldar social e culturalmente os trabalhadores, estendendo o controle gerencial para os lares e as comunidades operárias. Cf. MEYER III, Stephen. The five dollar day. Labor management and social control in the Ford Motor Company, 1908-1921. Albany, NY: State University of New York Press, 1981, p. 95-121.

18 Cf. ZELENY, Milan. Bat'a-system of management: managerial excellence found. Human Systems Management, n. 7, p. 213-219, 1983.

19 Sobre a viagem de Tomas Bata aos EUA, em 1919, cf. CEKOTA, op. cit., p. 143-150. Para o aumento da produção após a instalação da linha de montagem, cf. LE BOT, Florent. La "famille" du cuir contre Bata: malthusianisme, corporatisme, xénophobie et antisémitisme dans le monde de la chaussure en France, 19301950. Revue d' Histoire Moderne et Contemporaine, 52, n. 4, Paris: Belin, 2005, p. 134-135.

20 CEKOTA, op. cit., p. 271-284.

21 International Labour Office. Studies on industrial relations. Geneva, 1930, p. 243.

22 Ibidem, p. 243. 
período e no período em que não estavam nas fábricas eles frequentavam as aulas. ${ }^{23}$ Os alunos recebiam salários proporcionais aos dos trabalhadores em tempo integral e praticavam um "código de moral econômica" caracterizado pela obrigatoriedade de registrarem todos seus gastos num livro de contabilidade que era avaliado pelo diretor do albergue; além disso, parte de seus ganhos era compulsoriamente revertida para os cofres da empresa, que lhes pagava juros de $10 \%$ sobre as economias. ${ }^{24}$

Para Thomas J. Bata - filho do fundador -, a Bata School foi um dos fatores responsáveis pelo maior atributo da organização: o espírito dos empregados, o verdadeiro orgulho de fazer parte da corporação. A escola oferecia cerca de mil vagas anuais e chegou a receber 20 mil candidatos, o que se explicaria pela concepção de que ser um "homem Bata" era um símbolo de distinção e prova da capacidade do indivíduo pertencer a uma das mais exigentes e dinâmicas empresas da Checoslováquia. Muitos egressos ocuparam posições de responsabilidade dentro da organização e foram pioneiros na sua expansão. ${ }^{25}$

Outro elemento importante do sistema Bata foi construir habitações para alugar para os seus funcionários, em vilas dotadas de aparatos assistenciais, nos diferentes locais onde instalou unidades produtivas ao redor do mundo. A infraestrutura de tais vilas variou de local para local; sendo que as mais completas, construídas no país de origem, ofereceriam moradia, alojamentos, armazéns, creches, escolas, restaurantes, cinemas, campos, piscinas, igrejas, assistência médica e seguridade social. Assim como ocorria na escola, as despesas dos empregados da organização eram previamente calculadas e parte dos salários era aplicada nos fundos da empresa, que lhes pagava juros de $10 \%$ ao ano. ${ }^{26}$

Após a morte de Tomas Bata em 1932, seu irmão Jan Antonin Bata assumiu a direção da organização e, mesmo em meio à Grande Depressão, o grupo se expandiu significativamente. A ampliação dos negócios na conjuntura da depressão econômica fez parte das estratégias destinadas a contornar as políticas protecionistas adotadas por vários governos. Nesse sentido, pesquisadores constataram que a instalação das cadeias de loja na América Central e no Caribe teve melhores resultados para a companhia nos países sob domínio holandês e britânico, em função das condições mais favoráveis para a inserção das suas mercadorias a partir das exportações feitas pelas unidades produtivas estabelecidas na Holanda e na Inglaterra, o que Ihe possibilitou vender produtos sem taxação. ${ }^{27}$

Em 1939, Jan Bata exilou-se nos EUA - onde a Bata construiu uma companhia em Belcamp/Maryland -, devido à ocupação nazista da Checoslováquia, e se fixou

23 BATA, Thomas J.; SINCLAIR, Sonja. Bata: shoemaker to the world. Toronto: Stoddart, 1990, p. 3; e depoimento de Zdenek Pracuch ao autor. Franca, 12 de janeiro de 2009.

24 International Labour Office. op. cit., p. 243-245.

25 BATA; SINCLAIR, op. cit., p. 3.

26 Cf. dentre outros, ZELENY, op. cit.

27 PERUTKA, Lukas; BALABAN, Milan e HERMAN, Jan. The Presence of the Bat'a Shoe Company in Central America and the Caribbean in the Interwar Period (1920-1930). America Latina en la Historia Economica, v. 2, p. 42-76, 2018. 
posteriormente no Brasil. ${ }^{28}$ Os negócios no país de origem ficaram sob a administração de uma diretoria nomeada por ele; e, durante a guerra, os alemães designaram um interventor para administrá-los, sendo parte das instalações convertida para o esforço militar. No final dos anos 1940, após os comunistas tomarem o poder no país, as instalações da Bata foram estatizadas. O controle das empresas nos demais países foi objeto de intensa disputa judicial entre Thomas Bata, que se estabeleceu no Canadá em 1939 e para lá transferiu a sede administrativa da organização, e Jan Bata, ${ }^{29}$ que no Brasil fundou, em 1941, a Companhia SAPACO Comércio e Indústria e a vila operária Batatuba, construída no município de PiracaiaSP, distante cerca de 80 quilômetros da cidade de São Paulo, onde instalou uma fábrica de sapatos, um curtume e armazéns. ${ }^{30}$

Com o fim de compreender os métodos de gestão adotados pela organização, tenho dedicado atenção especial às estratégias de disciplinarização da força de trabalho, estabelecidas com o propósito de forjar uma força de trabalho condicionada ao ritmo de trabalho fabril, ordeira e identificada com os ideais da empresa. Um dos exemplos das ações destinadas a incutir nos trabalhadores padrões comportamentais baseados na moral do trabalho foi expresso por meio de frases grafadas nas paredes internas e externas das fábricas. No caso de Batatuba, as fotos das instalações possibilitaram observar as seguintes frases: "Somos Sapateiros"; "O trabalho é o melhor Educador"; "Amanhã será tarde, comece agora"; "O dia tem 86.400 segundos"; "Não olhe o obstáculo, olhe o alvo". Zeleny listou outros slogans: "Uma companhia - um interesse - um objetivo"; "Você perde tudo se você perde sua coragem"; "Trabalho é uma necessidade moral"; "Seja o primeiro"; "Honre seu trabalho". 31 Como se observa, a Bata enfatizava a importância do trabalho para formar pessoas dignas; do treinamento para se alcançar níveis de qualidade e de produtividade sempre crescentes, o que possibilitaria "servir aos clientes" de maneira mais eficiente, ao fabricar bons calçados e a preços acessíveis; do aproveitamento de cada segundo para a produção; e da lealdade e dedicação à empresa.

O controle exercido sobre os funcionários extrapolava o espaço produtivo e adentrava a esfera privada de suas vidas, por meio da concessão de incentivos financeiros para que eles parassem de beber, de fumar ou para perderem peso. ${ }^{32}$ Portanto, o universo autoritário de condicionamento psicológico foi um componente essencial do sistema Bata e seria reproduzido em diferentes países ao longo do século XX, constituindo um caso de totalitarismo empresarial,

28 Em 1941, Jan Bata, junto com familiares e diretores da organização, fixou residência no Brasil. Cf. ARCHANJO, Francisco Miguel. "O mundo compreenderá". A história de Jan A. Bata - o rei do sapato. Rio de Janeiro: Ed. Aurora, 1952.

29 A disputa judicial entre o tio e o sobrinho se prolongou por mais de duas décadas e, em 1966, o filho do fundador das empresas foi reconhecido como o legítimo proprietário e presidente da organização. Cf. dentre outros, BATA; SINCLAIR, op. cit., p. 140-161.

30 Jan Bata fundou as cidades de Mariápolis (SP), Bataguassu (MS), Batayporã (MS) e Anaurilândia (MS). No Mato Grosso do Sul, seus negócios voltaram-se para os ramos de colonização, fazendas, olarias e serrarias. Cf. ARCHANJO, op. cit. e depoimento de Zdenek Pracuch ao autor.

31 ZELENY, op. cit., p. 217.

32 Ibidem, p. 214. 
já que objetivava o domínio total sobre os trabalhadores e suas famílias, que seriam fontes do suprimento de força de trabalho disciplinada para as unidades produtivas e para as cadeias de lojas construídas mundo afora.

\section{O início das atividades produtivas no Brasil e no Chile}

A EXPANSÃo MUNDIAL DA BATA, iniciada por meio da instalação de lojas e de unidades produtivas em outros países europeus, visou ampliar seu mercado consumidor e fortalecer a organização, ao aproveitar-se, por exemplo, do fato de as fábricas instaladas no exterior poderem importar partes dos calçados da Checoslováquia sem pagar tarifas alfandegárias. Não raro, os industriais desses países acusaram a organização de buscar o monopólio do mercado calçadista e desencadearam manifestações contrárias à sua presença por meio de folhetos "anti-Bata" e da pressão junto aos governos para que estes restringissem as importações em defesa dos produtores locais. Essas campanhas se iniciaram na Alemanha e se estenderam à França, à Inglaterra, à Escandinávia e à lugoslávia nos anos $1920 .{ }^{33}$

Segundo Thomas J. Bata, em 1939, em meio às negociações estabelecidas com o governo do Canadá para transferir maquinário da Checoslováquia para aquele país e para a imigração de famílias de trabalhadores checos, a organização foi alvo de mais uma "campanha anti-Bata". Os fabricantes canadenses de calçados teriam encontrado fiéis aliados entre os líderes da United Shoes Machinery Corporation - companhia estadunidense de máquinas para calçados que exercia domínio mundial no setor por meio do sistema de leasing e que não tinha a Bata entre seus clientes - e delegações viajaram à Ottawa para fazer lobby junto ao governo, além de enviarem cartas aos jornais acusando a empresa checa de dumping e de comportamento antissocial. ${ }^{34}$

A chegada da Bata ao Brasil e ao Chile ocorreu nesse mesmo período, entre fins da década de 1930 e início dos anos 1940, num contexto de nacionalismos desenvolvimentistas e de industrialização por substituição de importações. Em linhas gerais, é possível afirmar que os dois países possuíram semelhanças no que diz respeito ao papel mais ativo que o Estado assumiu no desenvolvimento industrial, implantação de legislações sociais e trabalhistas, regulamentação dos sindicatos e necessidade de reconhecimento estatal, início da intensificação da urbanização e da migração do campo para as cidades, persistência da importância econômica dos setores exportadores (com destaque para os minérios no Chile e para a agricultura, sendo o café o principal item, no Brasil), bem como, a incapacidade para superar a extrema desigualdade social e o peso político de suas oligarquias. Uma diferença marcante entre os países refere-se à política, pois enquanto o Chile vivenciou, a partir de 1938, a importante experiência de um governo de Frente Popular de centro-esquerda (que inspirou

33 PERUTKA; BALABAN, e HERMAN, op. cit., p. 47.

34 BATA; SINCLAIR, op. cit., p. 60-61. 
os demais governos por pelo menos uma década), o que foi decisivo para o fortalecimento de uma tradição de esquerda partidária e da sua atuação em defesa dos interesses dos trabalhadores dentro da política institucional, o Brasil foi governado pela ditadura varguista do Estado Novo (1937-1945), que perseguiu opositores, reprimiu manifestações operárias, interveio em sindicatos e atuou com o fim de cooptá-los. ${ }^{35}$

De forma semelhante ao que ocorrera na Europa e no Canadá, a instalação da companhia no Chile, em 1939, fez com que industriais chilenos se organizassem em torno do Comité de Defensa de las Industrias del Cuero, del Calzado, de la Goma y Textiles para denunciar a ameaça de destruição que suas empresas sofriam e exigir do governo medidas protecionistas para os pequenos e médios produtores. O Comité instigou os trabalhadores do setor a aderirem ao movimento, se reuniu com representantes do governo, publicou textos em jornais de Santiago e formulou um documento para acusar a Bata de utilizar seu poderio econômico para explorar a ignorância popular e promover a concorrência desleal. ${ }^{36}$

Os responsáveis pela instalação da empresa no Chile não assistiram passivos à "campanha anti-Bata" e, além das negociações com o governo para evitar a interrupção do projeto em curso, recorreram aos jornais para desconstruir os principais argumentos mobilizados contra a sua chegada ao país. Sem identificação de autoria, foi publicada no jornal El Imparcial de Santiago uma série de artigos intitulados "A produção não é inimiga do trabalho". Argumentou-se que as inovações tecnológicas possibilitavam produzir em maior quantidade e produtos mais baratos, permitindo o acesso de toda a população aos calçados, algo imprescindível num país que ainda tinha muitos habitantes descalçados. Ao contrário das acusações, a Bata traria "bem-estar geral" por meio da "incorporação de novos capitais e [d]o aporte de novos esforços à obra superior de fomentar nossa produção, de dar a nossos operários trabalho bem remunerado e de criar atividades fecundas". ${ }^{37}$

A resolução da contenda se deu no final de julho de 1939, com a autorização governamental para o início da produção nos galpões construídos em Peñaflor, distante 34 quilômetros da capital. A pedido do ministro da Fazenda, estabeleceu-se o acordo de que inicialmente a Bata não fabricaria calçados de couro ou sintéticos, mas apenas produtos industriais derivados da borracha: botas longas de borracha, tecidos, correias transmissoras etc. Importaria a borracha e utilizaria couro e enxofre chileno; e também exportaria minerais chilenos para as suas fábricas ao redor do mundo. A empresa iniciou suas atividades sob a

35 Entre outros, CURY, Márcia. O protagonismo popular: experiências de classe e movimentos sociais na construção do socialismo chileno (1964-1973). Campinas, SP: Ed. da Unicamp, 2017, p. 33-98; COSTA, Hélio da. Em busca da memória. Comissão de fábrica, partido e sindicato no pós-guerra. São Paulo: Scritta, 1995; GOMES, Angela Maria de Castro. A invenção do trabalhismo. $2^{\mathrm{a}}$ ed. Rio de Janeiro: Relume Dumará, 1994; e LEOPOLDI, Maria Antonieta. A economia política do primeiro governo Vargas (1930-1945): a política econômica em tempos de turbulência. In: FERREIRA, Jorge; DELGADO, Lucilia de A. N. (org.) O Brasil Republicano. O tempo do nacional-estatismo. Rio de Janeiro: Civilização Brasileira, 2003, p. 241-285.

36 El Comité de Defensa de las Industrias del Cuero, del Calzado, de la Goma y Textiles. EI Monopolio "Bata": el peligro que su instalación en el pais significa para la industria nacional, los obreros y los consumidores. Santiago de Chile: s. e., 1939.

37 El Imparcial. La produccion no es enemiga del trabajo VI. Santiago, 25 jun. 1939. (tradução minha) 
designação "Manufacturera de caucho, tejidos y cueros S.A." CATECU e um dos chilenos responsáveis por sua instalação no país informou que seriam empregados 250 operários chilenos, que receberiam os mais altos salários, e que planejavam construir uma vila operária modelo e implementar o "sistema social Bata", reconhecido mundialmente como o mais completo. ${ }^{38}$ Não consegui precisar quando o acordo inicial deixou de vigorar, mas num curto espaço temporal a empresa passou a fabricar os mais variados tipos de calçados.

A produção no Chile começou em setembro de 1939 e, poucos anos depois, a empresa empregava 430 funcionários, sendo descrita como uma "alavanca formidável de progresso e grandeza econômica particular e coletiva". Suas atividades traziam "progresso e desenvolvimento local e nacional." ${ }^{39} \mathrm{O}$ entusiasmado jornalista que visitou as instalações em Peñaflor e entrevistou Jaromir Pridal - gerente industrial de origem checa - destacou a contribuição da empresa para o desenvolvimento do comércio local e, principalmente, para a melhoria do padrão de vida dos trabalhadores, pagando-lhes salários $15 \%$ superiores ao restante das indústrias.

Poucos meses depois, o mesmo jornal publicou mais uma reportagem resultante da visita realizada às instalações da empresa em Talagante, cidade vizinha à Peñaflor, onde foram adquiridas terras para construir um curtume e ampliar sua capacidade produtiva. $O$ anfitrião foi Dalibor Svoboda - executivo e engenheiro de origem checa - e o destaque coube à construção das primeiras casas destinadas aos funcionários e aos planos de erigir ali o povoado que se chamaria Bataflor. Svoboda explicou que as residências seriam alugadas "com todo o conforto e a higiene que exige a vida moderna. Há 25 casas prontas e 45 serão terminadas até o fim do ano." Os planos envolviam a construção de um povoado com o oferecimento de vários serviços por parte da empresa. "Assim, tudo está previsto para que o trabalho se faça agradável. Dessa maneira, a moral de nossos operários será também mais sã e mais alta."40

O executivo destacou ainda que a maioria dos funcionários da companhia não era estrangeira e que entre os onze checos que atuavam no Chile em cargos técnicos alguns haviam se casado com chilenas. Ao final, numa clara resposta à "campanha anti-Bata" de 1939, enfatizou que foram algumas vezes injustamente atacados e que todo o capital da empresa ficava no país e era ali revertido. A preocupação em associar constantemente as realizações da organização aos interesses nacionais, retratando-a como parte dos esforços para promover o progresso e o desenvolvimento do país, e a estratégia de afirmar que os gestores de origem

38 El Imparcial. Se instalara la firma Bata en nuestro pais, pero no se dedicara a fabricar zapatos. 1 ago. 1939. Reprodução do artigo publicado originalmente em La unión, de Valparaiso.

39 El Peñaflor. BATA y la industria del calzado en Chile. Factor de progreso es "BATA" en Peñaflor. Su labor social en favor de sus operarios. Interesantes declaraciones del gerente señor Pridal. Peñaflor, n. 2, 21 mar. 1942. (tradução minha)

40 Idem. Bataflor, una industria que extiende en la comuna y en el departamento trabajo y riqueza. n. 12, 1 ago. 1942. (tradução minha) Os planos de construção de Bataflor descritos por Svoboda não se efetivaram. O curtume funcionou em Talagante até os anos 1960, quando foi desativado após ser construído um novo na cidade de Melipilla, onde também foi instalada uma nova fábrica de calçados. A maior parte das construções projetadas para a extensa área adquirida em Talagante foi efetivada em Peñaflor. 
checa tornaram-se valorosos membros das comunidades locais, inteiramente integrados à coletividade, foram marcantes ao longo do período analisado.

Não localizei evidências de que a chegada da Bata ao Brasil, em 1941, e a construção das fábricas de calçados e de couros, bem como da vila operária, tenham desencadeado uma "campanha anti-Bata" tal como ocorreu noutros países. Não obstante, a fabricação de calçados sob o sistema Bata não se efetivou sem contratempos. A análise das edições do jornal Novidades de Batatuba possibilitou interpretar outra modalidade de conflitos decorrentes das reações aos princípios gerenciais formulados para auferir altos índices de produtividade em qualquer localidade em que a organização montasse unidades produtivas: as resistências operárias, materializadas principalmente nos atos de indisciplina. $O$ número inaugural da publicação trouxe na primeira página um texto que exaltava "A LEALDADE" como um dos principais atributos que a empresa esperava dos funcionários.

São principalmente sob dois aspectos que olhamos os homens: LEALDADE [e] CAPACIDADE.

A capacidade dos homens que não compreendem o sentido do dever, o sentido da lealdade, não interessa. - Por que? - Porque toda a capacidade sem lealdade fica inútil. Não é aproveitável, nem pela própria pessoa, nem pela companhia empregadora.

Dalealdade e da responsabilidade se formam os homens de responsabilidade. ${ }^{41}$

O motivo dessas assertivas foi uma paralisação envolvendo cerca de 40 trabalhadores em junho de 1942. A publicação não apresentou explicações a respeito dos motivos da ocorrência, limitando-se a afirmar que alguns funcionários deixaram de trabalhar no período da tarde por conta da pressão de "agitadores". Ao menos uma parte dos envolvidos foi demitida, pois o jornal informou que solicitaram a reinserção sob a alegação de terem sentido medo dos colegas que comandaram a ação. $\mathrm{O}$ autor do texto refutou com veemência essa justificativa: "o trabalho que está ligado ao futuro não perdoa falta de caráter. Aquele que teme lutar pelo seu trabalho e pelo seu serviço não merece esse serviço". A disposição em confrontar quem ameaçasse a paz social era imprescindível para o próprio desenvolvimento da comunidade, pois "Batatuba, como organismo vivo, não podia crescer, não podia progredir se a gente que forma essa cidade não defendê-la". O texto foi concluído com uma justificativa, em forma de indagação, para não reincorporar os demitidos: "Como podemos nós dar serviço àqueles que nos põe no risco de, na primeira ocasião, se deixarem levar por interesses contrários à Companhia?"42

Portanto, a empresa utilizou o primeiro número de seu veículo oficial de comunicação com os trabalhadores para afirmar que a lealdade era um pré-requisito indispensável aos seus "colaboradores" - expressão usual no Brasil e no Chile para se referir aos trabalhadores - e demonstrou a partir das demissões que paralisações eram absolutamente inaceitáveis, pois quebravam as regras de confiança que deveriam reger as relações de trabalho e ameaçavam

41 Novidades de Batatuba. A LEALDADE. a. 1, n. 1, 6 jun. 1942, p. 1. (caixa alta no original)

42 Novidades de Batatuba. A LEALDADE, p. 1-2. (grifos meus) 
a coesão da coletividade que estava se formando em Batatuba. A postura adotada para com os paredistas refletiu o objetivo de se forjar um corpo social homogêneo, constantemente vigiado e protegido das ameaças à paz social por meio do expurgo dos indesejáveis, o que seria possível a partir da colaboração entre a direção e os funcionários tidos como leais. Para tanto, era crucial fixar nos trabalhadores não apenas o princípio da lealdade como também o papel ativo que eles próprios deveriam desempenhar para assegurar a integridade do que definiu como um "organismo vivo".

Apesar de não ter localizado quaisquer outras informações a respeito da paralisação parcial de 1942, é relevante destacar que ela ocorreu durante o Estado Novo, quando a forte repressão ao movimento operário, combinada com estratégias variadas de cooptação dos sindicatos e de suas lideranças, dificultou significativamente a eclosão de movimentos paredistas. Nesse contexto, a paralisação ocorrida em Batatuba se soma às poucas greves à margem dos sindicatos ocorridas, por exemplo, em São Paulo. ${ }^{43}$ No final daquele ano, com a entrada em vigor da Lei de Esforço de Guerra, direitos trabalhistas foram suprimidos, penalidades foram estipuladas para o descumprimento das normas de trabalho e a participação em greves tornou-se passível de reclusão. ${ }^{44}$

Outras ações cotidianas relatadas no jornal Novidades de Batatuba demonstraram que contar com a lealdade e a plena colaboração de todos seus funcionários era um anseio difícil de ser concretizado. No início de julho de 1942, os trabalhadores foram informados que passariam a ser revistados na saída da fábrica devido ao fato de quase diariamente os gestores verificarem a falta de peças e de outros instrumentos. "Essas mãos que os tiraram são de empregados da Cia. De empregados que deveriam ser os primeiros a zelar pelo material da oficina que lhes dá o ganho diário." A empresa esperava "a ação decidida de nossos próprios colaboradores para afastar esses indivíduos perniciosos." ${ }^{\text {"4 }}$ Ao lado desse texto foi publicada a notícia elogiosa de que um aluno da Escola Industrial encontrara um relógio nas ruas de Batatuba e o devolvera ao dono após certificar-se de que se tratava do legítimo proprietário. ${ }^{46}$ Dessa forma, estabeleceu-se o contraste entre as duas ações com a finalidade de se demonstrar ao coletivo que a honestidade era um exemplo a ser seguido por todos, enquanto a desonestidade constituía uma grave doença a ser combatida.

A difusão no Brasil e no Chile da importância de valores como honestidade, honradez e lealdade foi recorrente nos textos endereçados aos trabalhadores. A partir de 1942, antes de a Bata publicar seu próprio jornal no Chile, ela utilizou um espaço no periódico El Peñaflor para noticiar a seção "Bata para sus colaboradores". Na $21^{a}$ edição, veio a público um texto também intitulado "Lealdade", destinado a afirmar que a falta de honra solapava a cooperação

43 Sobre as greves durante o Estado Novo, cf. COSTA, op. cit., p. 11-52.

44 Outra referência para o período é SILVA, Fernando Teixeira da. Os trabalhadores pe(r)dem a palavra (19371945). In: A carga e a culpa. Os operários das Docas de Santos: direitos e cultura de solidariedade. 19371968. São Paulo: Hucitec, 1995, p. 77-106.

45 Novidades de Batatuba. A má ovelha põe o rebanho a perder. a. 1, n. 4, 4 jul. 1942, p. 3.

46 Novidades de Batatuba. Procedimento justo. a 1, n. 4, p. 3. 
mútua e resultava da inveja e da deslealdade daqueles que não conseguiam triunfar na vida por meio do próprio esforço. "Juventude, companheiros de trabalho, recordem-se que só com lealdade e abnegação poderão chegar a conquistar o que aspiram, só o trabalho Ihes garantirá a felicidade e o bem-estar." ${ }^{\text {" }}$

Num diálogo reproduzido por Francisco Archanjo, Jan Bata detalhou os métodos empregados para formar "bons" trabalhadores - salários adequados, condições favoráveis, ambiente agradável, conforto e bem-estar geral para os funcionários e suas famílias -, mas advertiu que era impossível não lidar com desafios.

Há a questão da disciplina, especialmente, para aqueles que não foram na infância sujeitos a esse regime. A esses é preciso disciplinar. Não se aprende sem disciplina, que é a base do progresso. [...] Ah! Estou passando aqui em Batatuba, por idênticas dificuldades que se verificam em outras cidades: ensinar ao operário o ofício, mas de acordo com o nosso método. A princípio se rebelam contra a disciplina. ${ }^{48}$

Destarte, as publicações da Bata no Brasil e no Chile nos anos imediatamente posteriores ao início das suas atividades produtivas e a fala de Jan Bata após cerca de uma década de funcionamento da empresa no interior paulista possibilitaram observar, por um lado, alguns fundamentos do sistema Bata de domínio total: a construção de comunidades idealizadas para se transformarem em corpos sociais homogêneos e coesos; o estímulo ao convívio harmonioso entre todos os seus membros, cujas condutas seriam guiadas por valores constantemente reafirmados; e o objetivo de formar um operariado disciplinado, ordeiro e altamente produtivo. Por outro lado, os registros mostraram as dificuldades para efetivar o projeto: paralisação parcial dos trabalhos, furtos, danos causados aos instrumentos de trabalho e às matérias-primas, dificuldades técnicas, atrasos, produtividade inferior ao planejado e funcionários sem a capacitação necessária ou desinteressados.

\section{A replicação do sistema educacional}

No RETROSPECto ESCRITO POR JAN BATA, em 25 de janeiro de 1943, quando Batatuba completou um ano de fundação, ele destacou que "é o nosso lema não admitir os diretores, mas formá-los. De quem? Dos operários simples, educados, ensinados, aprovados. Todos os diretores do nosso trabalho foram vendedores, estoquistas, mestres, operários, antes de atingir posições elevadas e fortuna." 49 O método de ensino e o código disciplinar desenvolvidos na Bata School of Labor serviram de modelos para o propósito de formar seus próprios gestores a partir da inculcação de princípios administrativos, valores e normas de conduta nos alunos/ trabalhadores. Conforme um texto publicado pelo jornal Novidades de Batatuba, os alunos da

47 El Peñaflor. Lealtad. Peñaflor, n. 21, 23 jan. 1943. (tradução minha)

48 ARCHANJO, op. cit., p. 217. (grifos meus)

49 Novidades de Batatuba. Retrospecto de Batatuba. a. II, n. 28, 25 jan. 1943, p. 2. 
Escola Industrial de Batatuba tinham primazia dentro da organização "porque os batadores educados na nossa escola que Ihes ensina SERVIR em toda a acepção da palavra, eles, mais do que ninguém, se adaptam ao nosso sistema". ${ }^{50}$

As informações a respeito de Batatuba dão conta que jovens foram tomados como alunos desde o início da fabricação de calçados no país e os prédios que abrigaram a Escola Industrial e um alojamento para os internos foram construídos em conjunto com as casas da vila operária. Conforme mostra o excerto acima, foi cunhado inclusive o termo "batadores" - fusão das palavras Bata e trabalhadores - para se referir aos alunos, destinado a reforçar a identificação dos jovens para com a organização e servir como um elemento de distinção. A Escola Industrial chegou a ter pouco mais de 70 alunos, divididos em duas turmas, que frequentavam aulas de diferentes disciplinas no período noturno. ${ }^{51}$

Parte fundamental do processo formativo era seguir o rígido código disciplinar e foi adotado o modelo original de Zlín, inclusive a rotina diária: 5:40 - levantar; 6:00 - ginástica; 6:30 - café matinal; 7:00 - trabalho; 11:00 - almoço; 11:30 - ping-pong; 12:30 - trabalho; 17:00 - banho de chuveiro; 17:30 - jantar; 19:15 - escola; 21:30 - dormir. "Este horário deverá ser rigorosamente obedecido. O Sr. Pascoal Police [diretor da escola] estará encarregado da disciplina e obediência desse horário acima." ${ }^{52}$ Logo, até mesmo as atividades a serem desenvolvidas nos curtos tempos de ócio eram pré-determinadas pela direção. O controle da vestimenta também compunha as regras de conduta do grupo: cada aluno teria um uniforme de gala para as solenidades e um uniforme de trabalho; não se admitiria que se vestissem à sua maneira e tampouco que andassem descalços; e os uniformes deveriam ser limpos diariamente. "Dia a dia, maior disciplina e ordem para se alcançar o objetivo da Escola: preparar homens para a vida." 53

No Chile, o Colegio Industrial Bata (C.I.B.) foi fundado em 1942 e instalado em Peñaflor. ${ }^{54}$ Ao longo dos anos, além de alunos chilenos, com idade não inferior a 14 anos, recebeu regularmente jovens enviados por unidades produtivas instaladas em países como Bolívia e Peru. O depoente Luís Pinto Jeria ${ }^{55}$ ingressou na instituição em 1969 e, conforme relatou, os alunos continuavam a ser submetidos a uma rotina diária de trabalho e de estudos em tempo integral, mas as atividades laborais na fábrica foram restritas à meia jornada. $A$ rígida disciplina seguia os padrões advindos da Checoslováquia e marcou suas experiências enquanto interno.

50 Idem. A posição dos batadores. a. I, n. 2, 20 jun. 1942, p. 2.

51 Idem. Horário de Ensino da Escola Industrial. a. I, n. 5, 18 jul. 1942, p. 2.

52 Idem. AOS BATADORES. a. I, n. 5, 18 jul. 1942, p. 3. (caixa alta no original)

53 Idem. O uniforme do Batador. a. I, n. 7, 01 ago. 1942, p. 4.

54 Manual de Propaganda do Colegio Industrial Bata. Um camino para el futuro. Peñaflor, 196?

55 Chileno, nascido em 1951, filho único de uma família de camponeses que morava na zona rural de Melipilla e não tinha terra própria, formou-se no C.I.B., realizou vários cursos de aperfeiçoamento ao longo dos anos e exerceu cargos de gestão na organização nos primeiros 15 anos após se formar; em seguida, saiu da empresa e gerenciou duas fábricas de calçados no Chile, por cerca de sete anos; regressou à Bata Chile e nos anos 2000 atuou em unidades da organização na Malásia (gerente da produção de calçados de segurança), no Zimbabué (diretor) e no México (diretor); aposentou-se em 2017 e reside em Peñaflor, numa antiga casa construída pela empresa numa vila concebida para abrigar o pessoal da administração. 
Era um regime bem militar. 5:30 da manhã tínhamos que nos levantar e fazer atividades físicas. De 5:30 às 6:30 era atividade física. Sair a correr, no verão praticar esportes, fazer atletismo, e mesmo no inverno, eram todos os dias. Uma hora de atividade física. Depois voltar, arrumar o dormitório e tomar o café da manhã. Às 7:00 ou íamos para a aula ou íamos trabalhar. Porque tínhamos meia jornada de trabalho e meia jornada de estudos. [...] às 10:00 da noite se apagava tudo e íamos dormir, porque no outro dia tinha que estar de pé novamente. Então era um regime muito estrito, muito disciplinado. E pessoas jovens, de 16, 17 anos, tinham que Ihes inculcar disciplina. Tinham que nos formar para sermos bem duros, rigorosos. ${ }^{56}$

No Brasil, as estratégias para angariar alunos englobaram o estabelecimento de um convênio com a Superintendência de Ensino do Estado de São Paulo, que se comprometeu a enviar jovens das escolas profissionais mantidas pelo governo. ${ }^{57} \mathrm{De}$ acordo com Pascoal Police, "nosso esforço é colaborar com os poderes públicos e com a coletividade numa missão grandiosa: Servir o povo [sic]. Estamos esperando que, de Batatuba, saia uma mocidade briosa e trabalhadora, espelho dos jovens trabalhadores brasileiros". Dessa maneira, a missão de "servir" ao povo brasileiro não se restringia à fabricação de sapatos bons e baratos; englobava a formação de uma força de trabalho disciplinada. "Forjam-se novas fontes de trabalho e cria-se uma juventude, com ideias sãs e vontade de vencer." 58

Contudo, assim como ocorreu no chão de fábrica, marcado pelas dificuldades para se atingir o nível de qualidade almejado e a produtividade planificada, formar uma juventude condicionada ao sistema disciplinar da empresa não foi tarefa simples. O jornal Novidades de Batatuba registrou variados casos de indisciplina por parte dos alunos. Um exemplo foi a crítica ao fato de muitos deles comparecerem às aulas sem os devidos materiais, o que era inaceitável. "Um aluno na escola sem cadernos e sem lápis é como um soldado sem fuzil, na guerra." ${ }^{59}$ Noutra edição, relataram que durante os exames mensais havia alunos que se portavam como "erva daninha", usando meios ilícitos para resolver as questões. ${ }^{60}$ Além disso, o absenteísmo às aulas foi um problema constante e os professores reclamavam que muitos alunos apresentavam desculpas esfarrapadas para justificar a ausência. ${ }^{61}$

Tal como ocorreu no cotidiano fabril, a direção industrial utilizou diferentes estratégias para coibir a indisciplina dos alunos/trabalhadores e combinou ações repressivas com estímulos monetários para persuadi-los a se adequarem às normas disciplinares. Uma iniciativa bastante simbólica, derivada do modelo de Zlín, ${ }^{62}$ foi a eleição pelos próprios

56 Depoimento de Luis Pinto Jeria ao autor. Peñaflor, 1 set. 2018.

57 Novidades de Batatuba. Louvável espírito de cooperação. Batatuba, a. I, n. 1, 6 jun. 1942, p. 4.

De acordo com uma nota publicada na edição n. 6, 25 jul. 1942, a Escola Industrial da SAPACO foi oficialmente registrada junto à Superintendência de Educação Profissional e Doméstica de São Paulo em 2 de junho de 1942.

58 Idem. Jovens para nossas indústrias. a. I, n. 2, 20 jun. 1942, p. 3.

59 Novidades de Batatuba. Aos Batadores. a. I, n. 13, 19 set. 1942, p. 2, 3.

60 Idem. Os exames mensais. a. II, n. 38, 31 maio 1943, p. 3.

61 Idem. OS FALTOSOS. a. II, n. 38, 31 maio 1943, p. 3. (caixa alta no original)

62 Um capitão eleito pelos companheiros era responsável por dirigir a disciplina e a limpeza do alojamento ao longo de seis meses. Cf. International Labour Office. op. cit., p. 243. 
alunos de "julgadores" que teriam como tarefa fiscalizar e aplicar penalidades.

Ninguém julga melhor os atos alheios do que aqueles que convivem nesse meio e nele fazem a sua vida. [...] Cada mau ato praticado pelo batador será julgado pelo tribunal de seus companheiros que lhe imporão o devido castigo.

Não deve haver camaradagem nisso. Acima de tudo buscar o interesse da escola e a disciplina. O nome da organização. Os maus elementos vão ser localizados pelos próprios companheiros e castigados. Será maior ainda o arrependimento daquele que vê os próprios camaradas de trabalho e de Escola repudiando os seus atos. ${ }^{63}$

Quase um mês depois, se noticiou a eleição de três "batadores" que deveriam observar seus colegas com o propósito de assegurar que a Escola Industrial "conservasse sempre o seu nível cultural, trabalhador e disciplinar". A eleição representaria "mais uma etapa pelo progresso e desenvolvimento" e, para isso, os diretores confiavam no "espírito disciplinar" dos eleitos. ${ }^{64} \mathrm{~A}$ partir da concepção de que a camaradagem entre os alunos deveria ceder lugar à lealdade para com a empresa, Pascoal Police argumentou que cada rapaz deveria tomar "amor pela causa que defende" e ter consciência dos seus deveres "para procurar eliminar todo o mau elemento que com sua maldade poderia desencaminhar os seus companheiros" ${ }^{6} 6$ Dessa forma, buscava-se fragmentar a solidariedade horizontal entre os alunos e, ao mesmo tempo, utilizava-se a ameaça da exclusão com a finalidade de dobrar os insubmissos e compor um corpo social harmonioso. Frente às resistências, não tardou para que as expulsões se efetivassem:

A diretoria da Escola Industrial vem ultimamente processando uma limpeza entre os alunos. Todo o mau elemento batador está sendo dispensado de Batatuba para que a futura população desta cidade seja seleta. E, como má ovelha põe o rebanho a perder, nós, os batadores, nos alegramos e louvamos esse fato, para o nosso descanso e bem-estar. ${ }^{66}$

A respeito de a notícia ter sido escrita por um aluno, é relevante explicar que foi instituída uma seção - "A voz dos Batadores" - destinada a publicar notícias sobre os acontecimentos da Escola Industrial, suas atividades esportivas e também textos de autoria dos mais colaborativos e disciplinados. Esses textos tiveram como principais temáticas enaltecer o trabalho, a disciplina, a ordem, a Escola Industrial, o ato de servir à pátria por meio do trabalho honesto e expor o desejo de que o projeto de transformar Batatuba numa pujante cidade industrial fosse realizado num curto espaço de tempo.

Simultaneamente à aplicação das penalidades disciplinares, foram instituídos estímulos e retribuições, como concursos destinados a avaliar a dedicação, a frequência às aulas, o desempenho e a higiene pessoal. Um exemplo foi o concurso "Qual o batador que arruma melhor a sua cama e tem em melhor ordem os seus pertences?", que premiaria o vencedor

63 Novidades de Batatuba. Júri Batador. a. I, n. 6, 25 jul. 1942, p. 4. (grifos meus)

64 Idem. ELEITO O CONSELHO BATADOR. a. I, n. 10, 22 ago 1942, p. 2. (caixa alta no original)

65 Idem. COOPERAÇÃO. a. I, n. 13, 19 set. 1942, p. 2. (grifos meus)

66 Novidades de Batatuba. Expulsando as más ovelhas... a. I, n. 23, 28 nov. 1942, p. 3. 
com a soma de Cr\$50,00.67 Em complemento, a direção determinou a obrigatoriedade de se efetuar a "cada semana uma revista geral nos dormitórios e nos próprios rapazes, para verificar se houve progresso, constatar a higiene, a ordem reinante e, enfim, tudo o que possa influenciar para que o jovem se habitue ao espírito da disciplina". ${ }^{68}$ No primeiro exame, foram aprovados apenas 26 dos 73 jovens matriculados.

Outro componente de grande relevância para se interpretar as estratégias totalitárias empregadas pela Bata para condicionar psicologicamente seus alunos foi a composição de hinos. Uma nota publicada pelo Novidades de Batatuba, em agosto de 1942, informou que estava sob a responsabilidade "do senhor Vitor Grimela a composição da marcha dos batadores. Essa canção será sempre entoada pelos rapazes de nossa Escola Industrial, para que se lembrem de sua tarefa e de seu futuro". ${ }^{69}$ Não localizei informações que possibilitassem saber se a referida composição foi concluída, mas a publicação Bata Noticias deu conta que em diferentes solenidades realizadas no C.I.B. de Peñaflor, os internos entoavam o Hino ao Trabalho e a canção do Internato. ${ }^{70}$ Portanto, a elaboração de hinos ou canções ocorreu no Chile e, possivelmente, no Brasil e visou incutir nos jovens os preceitos organizacionais da empresa e, principalmente, estimular a identificação deles para com a organização, compondo o diversificado quadro totalitário de controle físico e mental.

O último elemento a ser analisado sobre as escolas industriais da Bata refere-se ao controle financeiro que a empresa exercia sobre os ganhos de seus alunos/trabalhadores. De acordo com o depoimento de Luis Pinto, o "código de moral econômica" foi replicado no C.I.B. do Chile: uma parte dos salários era descontada para pagar os custos do internado, outra parte era retida compulsoriamente pela empresa e o restante era usado para cobrir gastos variados, que deveriam ser anotados num livro de controle conferido pelo inspetor.

\begin{abstract}
Esse inspetor administrava junto com a gente esses recursos. [...] Resulta que você tinha que entregar esse documento, esse livreto toda semana. Tinha que colocar quanto precisava para comprar pasta de dente, xampu, coisas de asseio pessoal; necessito de 5 para a lavandeira, preciso lavar as minhas roupas; quero comprar um par de sapatos... Então, por exemplo, ao invés dos 25 que estavam mais ou menos estabelecidos, eu precisava receber 30. [...] Então no fundo, aquilo que estavam fazendo era te ensinar a administrar os seus recursos e segundo que tivesses uma cultura de economizar. Então assim como a disciplina militar, tinha a do controle financeiro. ${ }^{71}$
\end{abstract}

Um manual de propaganda do C.I.B. destacou que "uma parte importantíssima na educação teórica é a formação do caráter do estudante e o ensino de como aumentar seus bens

67 Idem. CONCURSO entre os rapazes. a. I, n. 8, 8 ago. 1942, p. 3.

68 Idem. EXCURSIONARAM A ATIBAIA OS VENCEDORES DA SEMANA 32. a. I, n. 11, 29 ago. 1942, p. 3.

69 Idem. Marcha dos Batadores. a. I, n. 9, 15 ago. 1942, p. 2.

70 Bata Noticias. PEDRO LUYO REGRESO AL PERU. Peñaflor, a. III, n. 33, 29 fev. 1956. (homenagem ao estudante peruano que após três anos no internato regressou ao país de origem formado como modelista de calçados); Idem. Manifestación... a. V, n. 90, 17 abr. 1959. (cerimônia em homenagem a Odo Daicar, Diretor da Bata na América Latina).

71 Depoimento de Luis Pinto Jeria ao autor. (grifos meus) 
mediante a contabilidade". ${ }^{72}$ Por isso, o saldo registrado no livreto de contabilidade deveria ser sempre positivo. O depoente Luis Pinto afirmou que eles eram proibidos de utilizar o dinheiro economizado ao longo dos três anos e que só recebiam as economias ao concluírem o curso ou no caso de abandono. A preocupação com a educação financeira dos alunos também foi destacada por Francisco Archanjo: "Nas indústrias Bata a economia é um princípio básico. Isto é de suma importância para a educação da juventude. A poupança fixa princípios de moral e dignidade". ${ }^{73}$ Para alcançar esses objetivos, era fundamental evitar intromissões externas e a empresa esperava "que os pais [tivessem] suficiente compreensão com a educação moral de seu filho, para não lhe pedir o dinheiro economizado, que ele mesmo deve saber administrar". Os candidatos a uma vaga no C.I.B. deviam inclusive apresentar uma "carta dos pais prometendo não pedir ao estudante o dinheiro que este economizasse durante sua permanência no trabalho". ${ }^{74}$

Além do uso reiterado do discurso de que produzir calçados carregava o significado mais profundo de "servir" aos países onde instalava fábricas, a Bata reproduziu em demasia a ideia de que por meio das suas escolas industriais formava homens honestos, honrados, dignos e aptos a trabalharem em prol do desenvolvimento de suas nações. Assim, a multinacional demonstrava uma preocupação permanente em não se colocar em oposição aos interesses nacionais; ao contrário, propagava que estava a serviço do desenvolvimento e do crescimento de países como o Brasil e o Chile.

\section{A extensão do domínio empresarial à esfera privada e o controle dos tempos de ócio}

NAS PUBLICAÇõES OFICIAIS DA EMPRESA e também em textos enaltecedores da Bata são comuns afirmações de que as escolhas de Peñaflor e de Piracaia relacionaram-se às belezas naturais dos dois lugares. Também foi fundamental estarem localizadas próximas a rios e a estradas, para assegurar o fornecimento de água e para facilitar o transporte de insumos e a circulação de mercadorias. Outro aspecto determinante foi o fato de não serem grandes centros populacionais, mas tampouco estarem demasiadamente distantes destes. A respeito da seleção do local onde se instalou a empresa no Canadá, Cekota acrescentou que a localização geográfica deveria ser distante "o suficiente para proteger a nova comunidade contra a influência das cidades grandes - que poderiam ser inimigas de uma vida privada saudável". ${ }^{75}$ Thomas Bata explicou que a aquisição de terrenos para a instalação das plantas fabris tinha como um dos critérios não serem localizados em centros manufatureiros onde o sistema Bata pudesse se chocar com práticas arcaicas arraigadas. ${ }^{76}$

\footnotetext{
72 Manual de Propaganda do Colegio Industrial Bata... (tradução minha)

73 ARCHANJO, op. cit., p. 220.

74 Manual de Propaganda do Colegio Industrial Bata... (tradução minha)

75 CEKOTA, Anthony. The stormy years of an extraordinary enterprise... Bata. 1932-1945. United States: Universum Solcol Publications, 1985, p. 152. (tradução minha)

76 BATA; SINCLAIR, op. cit., p. 242.
} 
Portanto, havia um fator político na escolha dos locais onde instalavam as futuras indústrias e formavam as comunidades fabris: dificultar interferências externas. Georgia da Costa apontou que os planos habitacionais incluíam a aquisição de extensas faixas de terra com a finalidade de envolver o entorno citadino e isolar ou minimizar a influência direta de outras iniciativas industriais ou de outras ideias. ${ }^{77}$ Portanto, o distanciamento geográfico visava um controle social mais eficiente e mais abrangente, compondo o projeto destinado a apartar os trabalhadores do contato, sobretudo, com possíveis influências políticas externas.

Diferentes autores interpretaram o sistema de construção de fábricas com vilas operárias como um tipo de dominação burguesa em que a posse das moradias pela empresa potencializou o domínio empresarial. ${ }^{78}$ Conforme sintetiza Leite Lopes, nesse sistema de dominação ocorre: a extensão do controle fabril para o interior das casas, do tempo livre e do lazer dos trabalhadores, fazendo com que as vilas se constituam em espaços onde impera a disciplina e a moradia higiênica; o controle ideológico e político; o maior fechamento em relação ao mundo exterior; o controle patronal de uma série de recursos acessórios à moradia e essenciais à reprodução dos trabalhadores; a possibilidade de assegurar a assiduidade e a pontualidade, além de se exigir horas extraordinárias; e, ainda que não fosse regra, a possibilidade de as empresas aumentarem seus lucros por meio da cobrança de aluguéis, não raro, superiores aos valores de mercado. ${ }^{79}$

Não encontrei evidências de que a Bata tenha cobrado aluguéis abusivos dos trabalhadores no Brasil e no Chile. Além disso, as dimensões das vilas construídas nos dois países foram diminutas, principalmente, em comparação com a dimensão da cidade industrial edificada em Zlín. Em Batatuba, o projeto de um centro industrial de amplas dimensões não se efetivou, e em Peñaflor, a maior parte das residências operárias foi construída por meio das cooperativas habitacionais formadas e administradas pelos próprios trabalhadores. As casas construídas pela empresa no Chile destinaram-se prioritariamente aos gestores e aos funcionários da administração. Contudo, se não foi possível analisar a intensificação da exploração econômica da força de trabalho por meio da cobrança de aluguéis abusivos, obtive evidências abundantes a respeito da extensão do domínio empresarial à esfera privada e aos tempos de ócio dos trabalhadores.

A empresa definiu como uma obrigação dos ocupantes dos imóveis cuidarem da sua manutenção e das áreas externas. Nos primeiros dois números do Novidades de Batatuba, foram publicados textos que estimulavam os moradores a cultivarem jardins, projetados para

77 COSTA, Georgia C. C. da. As cidades da Companhia Bata (1918-1940) e de Jan Antonin Bata (19401965). Relações entre a experiência internacional e a brasileira. Dissertação (Mestrado em Arquitetura) - FAU, USP, São Paulo, 2012, p. 73.

78 Cf. dentre outros BLAY, Eva Alterman. Eu não tenho onde morar: vilas operárias na cidade de São Paulo. São Paulo: Nobel, 1985; LOPES, op. cit.; VERGARA, Ángela; DINIUS, Oliver J. (edit.). Company Towns in the Americas. Landscape, power, and working-class communities. Georgia: University of Georgia Press, 2011.

79 LOPES, José Sérgio Leite. Fábrica e vila operária: considerações sobre uma forma de servidão burguesa. In: Mudança social no Nordeste: a reprodução da subordinação. Rio de Janeiro: Paz e Terra, 1979, p. 41-98. 
compor o ambiente hospitaleiro e saudável que a vila deveria adquirir. ${ }^{80}$ Mas assim como ocorreu dentro da fábrica e na Escola Industrial, nem todos os moradores demonstraram a colaboração e a dedicação almejadas pela companhia. ${ }^{81} \mathrm{~A}$ cobrança não surtiu o efeito desejado e recorreu-se ao incentivo financeiro via promoção de um concurso de jardins destinado a embelezar Batatuba, pois "as flores são um complemento da beleza da alma. Inspiram sentimentos nobres. Indicam cuidado, zelo e delicadeza. Viver entre flores, trabalhar num lugar cercado de rosa traz ao espírito uma elevação sempre crescente". ${ }^{22}$ A constituição de um espaço aprazível e higiênico era parte do projeto totalitário de organizar um corpo social disciplinado, destinado a habitar locais quase idílicos. Ao definir como dever dos moradores o cultivo dos jardins, observa-se ainda o propósito de controlar uma parte dos seus tempos de ócio, já que eles foram orientados a dedicar ao menos uma hora diária, após a labuta cotidiana, àquela tarefa.

O tema também foi objeto de uma nota publicada no Chile pelo jornal Bata Noticias. O Chefe do Departamento de Segurança da empresa informou que cada morador deveria realizar uma cuidadosa manutenção do exterior e dos arredores de suas residências e os instruiu a respeito da necessidade de plantarem grama ou flores. Indicou as espécies mais recomendadas em função da resistência e da durabilidade e afirmou que "os jardins devem ser limpos e bem cultivados. Portas, janelas e marquises pintadas. Os que ainda não tenham feito devem cumprir com essa obrigação". Para ele, "a ordem e a limpeza são dignas de cultura e bom gosto. Recebamos a primavera com otimismo e alegria e as Festas Pátrias com dignidade e orgulho de cidadãos conscientes de seu dever". ${ }^{33}$ As comemorações em torno do 18 de setembro constituem a principal festividade dos chilenos, tendo enorme apelo popular, e ao relacionar a obrigação dos trabalhadores realizarem a manutenção das casas e de cultivarem jardins com tais comemorações, observamos como a companhia mobilizava o sentimento nacional a favor do seu projeto de domínio total.

No que diz respeito ao patriotismo, em 1942, numa cerimônia em comemoração à proclamação da República no Brasil, Jan Bata discursou para as crianças do ensino primário do grupo escolar de Batatuba. Iniciou apontando a grandeza e o potencial econômico do Brasil, que tinha um território equivalente ao da Europa, com menos pessoas e sem ter passado sistematicamente por guerras, e assinalou que as crianças teriam motivos para se orgulharem do país em que viviam, mas também tinham deveres.

Os deveres de estudar, aprender o melhor que podeis. [...]

Esta Batatuba era dois anos atrás um recanto triste. Agora está melhorando rapidamente. Porque chegou aqui uma quantidade de gente que estudou muito e ama o povo e a terra brasileira.

80 Segundo Brandes, o movimento de embelezamento das fábricas e dos lares foi um aspecto importante do welfare capitalism nos EUA, e centenas de empresas plantaram arbustos e flores e promoveram concursos anuais de jardins de casas. BRANDES, op. cit., p. 34.

81 Novidades de Batatuba. OS JARDINS. a. I, n. 1, 6 jun. 1942, p. 4.

82 Idem. A necessidade dos jardins. a. I, n. 2, 20 jun. 1942, p. 2.

83 Bata Noticias. A los vecinos de las Poblaciones Bata. s. n., 16 set. 1961. (tradução minha) 
O amor da gente estudada exprime-se no trabalho. Não existe outra forma de ser expressado o amor pela Pátria.

Vós estais presenciando o milagre do erguimento de uma cidade industrial no Brasil.

Tendes a honra de estar entre os pioneiros de Batatuba.

Não vos esqueceis nunca. [...]

Por isso estais estudando. E esse é o modo pelo qual deveis provar o vosso amor pelo Brasil. ${ }^{84}$

Mesmo discursando para crianças de pouca idade, Jan Bata se dirigiu a elas como futura força de trabalho e reforçou o princípio de que seus empreendimentos eram conduzidos para servir aos interesses nacionais. Também mencionou os grandiosos planos que tinha para aquela localidade e, sem rodeios, enfatizou que a função de seus pequenos ouvintes era estudar para se tornarem futuros trabalhadores eficientes, responsáveis por executar os planos que ele projetara para Batatuba.

No Chile, a administração direta dos negócios ficou a cargo dos gestores e Thomas Bata realizou visitas periódicas ao país, frequentemente acompanhado pela esposa Sonja Bata e algumas vezes pelo filho. Nessas ocasiões, foram realizadas grandes recepções e, não raro, festas. O depoente Josef Murer ${ }^{85}$ afirmou que "para muitos, era como uma visita de um chefe de Estado". ${ }^{86}$ Em abril de 1962, por exemplo, a 132 edição do Bata Noticias teve como destaque uma dessas visitas e algumas fotos do casal publicadas pelo jornal continuam a adornar os restaurantes de Peñaflor. Thomas Bata conduziu a inauguração do supermercado montado por uma cooperativa de trabalhadores da companhia e afirmou ter se sentido feliz quando recebeu a notícia dos planos dos funcionários, "pois vi com agrado que poderia cooperar com vocês neste ato de bem [-estar] social, coisa possível de se fazer sempre que existam êxitos no trabalho". Destacou que os próprios trabalhadores administrariam o negócio e que dependeria "unicamente da sua cooperação e da administração honrada e dinâmica que lhe darão colher o êxito ou o fracasso e o maior ou menor benefício e comodidade para vocês e suas famílias". ${ }^{87}$ Sonja Bata, simbolicamente, realizou a primeira compra e um padre se encarregou de abençoar o estabelecimento.

84 Novidades de Batatuba. Palavras do Dr. Jan A. Bata às crianças. a. I, n. 22, 21 nov. 1942, p. 1. (grifos meus) 85 Nascido em 1934, num povoado da Morávia, emigrou da Checoslováquia em 1952 devido a divergências políticas com o regime comunista; estudou Filosofia por quatro anos em Roma e pretendia ser padre, mas renunciou ao sacerdócio; em 1956, migrou para o Chile como refugiado político; conhecia pessoas ligadas à Igreja Católica que estavam no país e, em 1959, ingressou na Bata, por intermédio de sacerdotes com ligações com a empresa; trabalhou inicialmente no Departamento de Custos e depois passou a gerenciar o Departamento de Compras. Devido à vitória da Unidade Popular, em 1970, decidiu sair do país e a serviço da Bata exerceu cargos de gestor no Peru, na Bolívia, no México e na Austrália. Em janeiro de 1974, regressou ao Chile sob a ditadura de Augusto Pinochet e, em 1978, foi transferido para o Brasil (empresa Âncora em Minas Gerais, de propriedade da organização mundial dirigida por Thomas Bata e sem ligações com os herdeiros de Jan Bata), onde viveu por dez anos; chegou a ocupar a coordenação das Companhias da América Latina e Caribe, sendo responsável pelas auditorias. Regressou ao Chile em 1989 e aposentou-se em 1999, após 40 anos de serviços prestados à organização. No momento da entrevista, morava em Peñaflor, numa das antigas casas construídas pela companhia para os funcionários da administração.

86 Depoimento de Josef Murer ao autor. Peñaflor, 27 ago. 2018.

87 Bata Noticias. Los anhelos de ayer son uma realidad. a. VIII, n. 132, 13 abr. 1962. 
Noutra notícia, destacou-se que, entre seus múltiplos negócios, Thomas Bata encontrou tempo para "pensar em Peñaflor" e que iria presenteá-la com um Liceu. Seu altruísmo e generosidade possibilitariam às futuras gerações peñaflorinas um caminho baseado nas ciências e na verdade. Em mais um discurso, o empresário afirmou que o Chile progrediu bastante desde sua última visita e que observava em suas viagens que "o progresso em geral tem avançado consideravelmente, ou seja, todos os povos do mundo estão evoluindo de forma muito rápida". Por isso, "para se progredir constantemente em todas as partes é necessária gente mais preparada e com maiores conhecimentos". ${ }^{88}$ Explicou que Juan Krippel, gerente geral da CATECU, havia Ihe informado que um representante do Ministério da Educação assegurara que se houvesse a doação do prédio, seriam disponibilizados professores para lecionarem. Thomas Bata apresentou então uma maquete do Liceu e disse que esperava vê-lo em funcionamento na sua próxima visita.

Não localizei um único exemplar do noticiário da empresa referente ao período entre 1963 e 1969, mas uma notícia a respeito de Antonio Batek, gerente geral da companhia no Chile, ter sido homenageado por uma turma de formandos trouxe a informação de que, em 1964, Thomas Bata entregou o "reluzente edifício do Liceu de Peñaflor". A participação de Batek na cerimônia de formatura possibilita interpretar como uma parte da população local se relacionava com alguns executivos da empresa. A entrega dos diplomas a cerca de 60 alunos foi realizada na Sede Social do Clube Esportivo Tomas Bata, em 12 de dezembro de 1970, e a oradora da turma afirmou:

[...] ao cumprir esta etapa, o $6^{\circ} \mathrm{Ano} A$ me encarrega de recordar que há alguns anos o Senhor Thomas Bata doava o moderno edifício onde passamos estes anos de estudos, desejamos expressar na pessoa do Senhor Antonio Batek, Diretor Gerente da Companhia no Chile, e que neste momento nos honra ao apadrinhar nossa graduação, que nos sentimos realizados por ter superado com êxito essa etapa, já que assim também contribuímos para justificar a sã intenção e os propósitos que motivaram o Senhor Thomas Bata a determinar o início da construção do Liceu. ${ }^{89}$

A realização da cerimônia na sede do clube da empresa, fato que se repetiu em vários anos, ilustra como a influência da Bata no município se estendia para além dos limites físicos das suas unidades produtivas, pois mesmo os habitantes que não trabalhavam nas fábricas frequentavam seus espaços de lazer. Para conseguir a adesão dos funcionários e da população em geral, as publicações da empresa noticiaram constantemente a participação dos executivos nas festividades locais ou a contribuição financeira para viabilizá-las. Os jornais e as revistas foram utilizados para difundir o discurso de que a Bata promovia o bem-estar em geral e que desempenhava um importante papel para o desenvolvimento local e nacional. As homenagens da população aos diretores da empresa indicam que ao menos uma parte da comunidade peñaflorina tendeu a legitimar o domínio da Bata ao reivindicar a participação dos gestores nos seus eventos sociais.

88 Idem. NUEVO LICEO PARA PEÑAFLOR. n. 132, 13 abr. 1962. (tradução minha)

89 Bata Noticias Chile. Discurso de la graduación. a. II, n. 6, jan. 1971, p. 16. 
A presença física de Thomas Bata e dos seus familiares no Chile foi carregada de grande simbolismo, mas no dia a dia cabia aos executivos demonstrar ao público o poder da organização mundial e propalar sua benevolência. Imbuídos da concepção de responsabilidade social, vários deles foram membros do Rotary Clube e do Lions Clube de Peñaflor e coordenaram inúmeras ações desenvolvidas por essas entidades, sempre noticiadas nas publicações da empresa. Jaromir Pridal, por exemplo, foi um personagem com grande influência junto aos habitantes da cidade; era um dos "pioneiros"90 e até hoje os saudosistas compartilham fotos dele a trabalhar nas obras de construção das primeiras edificações da empresa em Peñaflor. Pridal chegou a ser descrito pelo jornal Bata Noticias como a personificação da vontade de trabalho do fundador da organização. ${ }^{91}$

A maneira como a Bata lidou com a questão habitacional no Chile, entre fins dos anos 1960 e o início da década de 1970, ilustrou de forma inequívoca como alguns de seus mais altos executivos no país fizeram-se presentes em festas e solenidades operárias com a finalidade de afirmar o poder total da organização. Durante o governo do democrata cristão Eduardo Frei, ocorreram três grandes greves na empresa - em 1965, em 1966 e em 1968 -, cada uma com mais de um mês de duração. Na greve de 1966, o jornal El Siglo - publicação do Partido Comunista do Chile - enviou um repórter a Peñaflor que, após ouvir vários operários, publicou uma notícia destinada a desmistificar o discurso da empresa a respeito do alto padrão de vida desfrutado por seus funcionários. A reportagem denunciou as péssimas condições de vida de muitos trabalhadores e publicou uma foto de um barraco ocupado por uma trabalhadora da Bata e uma foto da mansão do gerente geral. ${ }^{92}$

Não consegui precisar o ano exato em que a empresa decidiu trocar seu gerente geral, mas obtive informações de que a decisão resultou dos desdobramentos de um desses movimentos paredistas. Segundo o depoente Josef Murer, uma das greves "obrigou que se fosse o gerente geral"; Juan Krippel foi para o Peru e Antonio Batek assumiu a direção da Bata no Chile. "É que a Companhia, para melhorar sua imagem, fez isso."93 Até 1972, Batek esteve à frente da empresa no país e mostrou-se bastante atuante, participando de inúmeros eventos sociais nas unidades produtivas, nas lojas distribuídas por todo o país e nas comunidades. Sua atuação pública dedicou-se, entre outros objetivos, a reverter a imagem de que muitos trabalhadores da Bata viviam sob péssimas condições de moradia, enquanto seus

90 Idem. PIONEROS... s. n., 17 set. 1959. Edição comemorativa dos 20 anos da CATECU. Os "pioneiros" eram Jaromir Pridal - Gerente técnico; Juan Krippel - Gerente geral; Vaclav Kucera; Juan Boros H.; Juan Zika; Antonio Lisowicz; Blahoslav Pazdirek S.; José Oplustil L. "O espírito humano raramente encontra a palavra apropriada para traduzir os verdadeiros sentimentos de gratidão para com aqueles homens que, sacrificando seu bem-estar, sua comodidade, a tranquilidade de seus lares, se lançaram à busca de novos horizontes, de novas terras onde semear sua semente de trabalho e de esforço, de sacrifício e de abnegação para recolher, ao cabo do tempo os ótimos frutos de uma produção material abundante e o reconhecimento dos corações..."

91 Bata Noticias. RECORDANDO AL FUNDADOR. a. III, n. 42, 18 jul.1956. (tradução minha) Entre outras atividades, Pridal presidiu o Clube Social e Esportivo Tomas Bata por 26 anos e, quando deixou o cargo, foi homenageado com o título de presidente honorário vitalício. Bata Noticias Chile. Primer Presidente Honorario Vitalicio. a. II, n. 8, mar./abr. 1971, p. 38.

92 El Siglo. Los ricos obreros de Bata que viven en una callampa. Santiago, 15 set. 1966, p. 11.

93 Depoimento de Josef Murer ao autor. 
executivos viviam luxuosamente. Visto que a maioria absoluta das moradias operárias foi construída pelas cooperativas habitacionais de trabalhadores, o gerente geral fez-se presente nas reuniões de fundação das cooperativas, nas festas de comemoração da conclusão de etapas das construções, nas cerimônias de entrega das chaves e assim por diante. Nos seus discursos, Batek afiançava que a empresa contribuía de maneira decisiva para possibilitar que seus funcionários realizassem o sonho de conquistar a casa própria.

Como tenho demonstrado, as publicações da Bata no Brasil e no Chile seguiram um mesmo padrão discursivo na abordagem das ações destinadas a moldar os comportamentos e os hábitos dos funcionários, assim como os de seus familiares, fora da esfera fabril. Ao abordar a questão dos furtos ocorridos na SAPACO, mencionei o elogio feito ao aluno que encontrou e devolveu ao dono um relógio. A ação deveria servir de inspiração aos demais moradores de Batatuba, pois "a honestidade é um dos deveres que fazem o homem feliz e digno do meio em que vive". ${ }^{94}$ Ocorrências similares foram noticiadas repetidamente nas publicações chilenas. ${ }^{95}$ Entre muitos exemplos, um dos mais emblemáticos foi o caso de um garoto de oito anos de idade, filho de um trabalhador da Bata, que ao voltar da escola encontrou um relógio feminino na rua e prontamente o levou ao Escritório de Pessoal da empresa. ${ }^{96}$

Com o intuito de instigar as mudanças comportamentais e a prática de atividades consideradas mais adequadas ao desenvolvimento pessoal, os redatores das publicações da Bata estimularam o interesse dos trabalhadores pela leitura durante seus tempos de ócio e incentivaram a constituição de bibliotecas. Em 1957, o Bata Noticias afirmou que "como as ferramentas de trabalho, os livros se enobrecem com o uso. A honradez e a verdade são atributos mais valiosos que as pedras preciosas e ao mesmo tempo brilham eternamente. Uma biblioteca, ainda que pequena, é necessária no lar". ${ }^{97}$ No Brasil, o Novidades de Batatuba publicou diferentes notas tratando das ações empreendidas para se constituir uma biblioteca pública na vila. O estímulo à leitura se desdobrou ao incentivo aos estudos de forma mais ampla. Para isso, os casos de funcionários chilenos que se destacaram enquanto estudantes foram noticiados como mais um exemplo a ser seguido por quem almejava ascender socialmente e na hierarquia interna da empresa. ${ }^{98}$

O objetivo de controlar a maneira como os trabalhadores administravam seus tempos livres fez-se presente desde os anos iniciais da instalação das unidades produtivas na América Latina. Nos anos 1940, alguns textos publicados no jornal El Peñaflor, assinados por "El Hálcon", abordaram diretamente esse tema. Em um deles, o autor aconselhou os jovens a se dedicarem com afinco ao trabalho para conseguirem o que ambicionavam.

94 Novidades de Batatuba. Procedimento justo. a. I, n. 4, 4 jul. 1942, p. 3.

95 Por exemplo, Bata Noticias. Gesto de Honradez. a. V, n. 90, 17 abr. 1959; Idem. Imitemos. s. n., 01 jun. 1959.

96 Idem. s.n., 10 jun. 1961.

97 Idem. Sabía usted que...?. a. V, n. 68, 30 nov. 1957. (tradução minha)

98 Por exemplo, EI Peñaflor. Bata para sus colaboradores. n. 10, 4 jul. 1942; Bata Noticias Chile. Resultados del ultimo curso del Liceo Vespertino Bata-Peñaflor. n. 8, mar./abr. 1971, p. 37; Idem. Ascenso para los trabajadores de Bata - Universidad. n. 9, maio 1971, p. 41. 
Evite gastar mal seu tempo livre - dedique-o à leitura e ao entretenimento são, pratique esporte e se eduque por meio de espetáculos culturais. Fuja dos vícios, não destrua sua saúde, que é seu bem mais precioso. Mantenha seu espírito alegre, seu corpo limpo e seu coração puro e tenha a certeza que conquistará o bem-estar para si e para os que lhe são queridos. SERÁS UM HOMEM. ${ }^{99}$

Em outro texto assinado por "El Hálcon" foram abordados diferentes temas, como a necessidade de saber administrar os próprios salários, de sempre poupar uma parte dos ganhos e a orientação veemente para que a juventude fugisse dos vícios.

É penoso ver os homens gastarem seus salários que custaram dias de sacrifício e esforço em bares e vícios de diversas espécies enquanto suas famílias carecem do necessário. [...]

Infelizmente, a juventude de hoje é uma raça de chupadores de cigarros, envenenada com álcool e saturada com vícios de toda espécie. Não tem vontade e nem ideais. [...] No álcool e no vício se perdem os filhos da pátria e a esperança do mundo. ${ }^{100}$

A preocupação com a dependência química, em especial com o alcoolismo, continuou presente nas décadas seguintes e uma ação de relevo foi o apoio à fundação de uma sede do Clube de Abstêmios do Chile em Peñaflor, nos idos de 1970. Num texto publicado pela revista Bata Noticias Chile, Gustavo Caruman Soto, presidente do clube, explicou aos leitores que o alcoólatra era um doente que demandava tratamento. Pouco tempo depois, noticiou-se que a Gerência de Relações Industriais promoveu uma campanha antialcoólica na empresa; e, em 1972, uma nota informou sobre a entrega de um cheque ao referido clube, por parte do gerente geral da companhia, com a finalidade de auxiliar a compra de medicamentos para o tratamento dos alcoólatras. ${ }^{101}$

Os excertos dos textos de "El Hálcon" indicaram uma grande preocupação do autor para com a necessidade de o tempo livre ser despendido de forma produtiva, por meio de divertimentos que possibilitassem um incremento cultural e pela prática de esportes, indispensáveis para a constituição de corpos saudáveis. Oferecer aos trabalhadores e aos seus familiares formas de entretenimento consideradas adequadas foi o princípio norteador da organização na construção dos clubes sociais e esportivos. Em maio de 1942, uma nota publicada a respeito das comemorações do $1^{\circ}$ de maio em Peñaflor destacou que a direção do Deportivo Bata "sem poupar sacrifícios nem esforços, dedica seu tempo livre a trabalhar para oferecer a seus associados entretenimentos sãos, que permitam gozar em seu descanso de distrações coletivas em estreita comunhão com seus familiares e companheiros de trabalho". ${ }^{102}$ A afirmação a respeito da promoção de divertimentos "sãos" foi recorrente e se

99 El Peñaflor. Adelante!. n. 10, 4 jul. 1942. (caixa alta no original; grifos e tradução minha)

100 El Peñaflor. Algunos consejos a los jóvenes. n. 18, 7 nov. 1942. (grifos e tradução minha)

101 Bata Noticias Chile. Club de Abstemios de Chile. a. I, n. 2, ago. 1970; Idem. Club de Abstemios de Chile. a. I, n. 4, out. 1970, p. 23; Idem. Club de Abstemios de Chile. a. III, n. 16, jan./fev. de 1972, p. 44.

102 El Peñaflor. El Deportivo Bata. n. 6, 9 maio 1942. 
relacionava à determinação de os trabalhadores se portarem de modo ordeiro e disciplinado mesmo nos seus momentos de lazer.

Dessa forma, o incentivo à prática de esportes adquiriu um papel importante no processo de disciplinar os trabalhadores nos espaços fora das fábricas. Além de estimular a prática de atividades físicas por todos os membros das comunidades, verifiquei o objetivo de se utilizar o esporte para moldar de forma ainda mais eficiente o comportamento dos trabalhadores que representavam a empresa em jogos amistosos ou em competições oficiais, pois a disciplina demandada para se tornar um atleta implicava seguir rotinas metódicas de preparação física e de treinos. Adicionalmente, era indispensável demonstrar comprometimento para com o coletivo, dedicação e disposição para seguir regras e padrões considerados adequados àqueles que representavam publicamente a imagem da empresa.

A Bata não utilizou o esporte somente com o objetivo de incutir nos atletas normas comportamentais e de conduta. Outro uso de grande relevância foi promover a identificação dos trabalhadores e das comunidades locais com a empresa. Ao analisar a replicação do modelo educacional no Brasil e no Chile, destaquei o fato de criarem o termo "batadores" para se referir aos alunos de Batatuba. No Chile, foi cunhado o termo "batino", que não se restringiu a designar os alunos do C.I.B. e abrangeu toda a coletividade que se formou em torno da empresa. Desde as primeiras notícias publicadas no El Peñaflor, em 1942, a designação foi empregada para se referir às equipes esportivas, aos trabalhadores, às crianças nascidas na comunidade e assim por diante. Expressões como "família batina" compuseram a linguagem da comunidade e foram inclusive incorporadas por alguns entrevistados, que afirmaram sentir orgulho de serem "batinos". ${ }^{103}$

Para conseguir essa adesão, o esporte teve um papel fundamental, pois constituiu uma das principais formas de lazer não apenas dos praticantes, como também dos espectadores que acompanhavam e torciam pelas equipes da Bata em diferentes modalidades esportivas. Vejamos, por exemplo, a notícia a respeito da calorosa recepção aos ciclistas da Bata que tinham se destacado nas provas de estrada e de velódromo em abril de 1961: as conquistas "confirmam o excelente estado em que se encontram nossos defensores e o pleno entendimento que existe entre dirigentes e dirigidos". Os ciclistas competiam "com ânsia de demonstrar que compõem com gosto as fileiras do Clube Esportivo Tomas Bata e que se vestem a camisa azul do Clube é porque a sentem em seu próprio ser e não estão dispostos a vê-la em lugares secundários, enquanto eles possam fazer algo para conquistar os lugares de destaque". ${ }^{104}$

103 A forte identificação dos operários para com as empresas, manifestada por meio de termos que faziam menção aos nomes dos fundadores, não foi exclusividade da Bata. No Chile, o paternalismo industrial da Sociedad Nacional de Paños de Tomé, entre as décadas de 1910 e 1940, teve como uma de suas expressões a definição do bom operário "serranista" - menção ao fundador Marcos Serrano Menchaca - como aquele que era responsável, esforçado, comprometido e defensor dos interesses da indústria; e os próprios trabalhadores se distinguiram como "serranistas" quando defenderam as cores e o nome da empresa em competições esportivas. Cf. VENEGAS VALDEBENITO; MORALES BARRIENTOS, op. cit.

104 Bata Noticias. OUTRA VEZ... a. VI, n. 121, 22 abr. 1961. (tradução minha) 
Os inúmeros triunfos das equipes da Bata, com destaque para as várias conquistas no futebol amador e para um título inédito no basquetebol - em 1967 a equipe representou Santiago no Campeonato Sul-Americano de Clubes Campeões, realizado em AntofagastaChile, e sagrou-se campeã -, serviram para reforçar ainda mais a identificação da população local para com a empresa. Assim como as edificações erguidas em prol da comunidade, os títulos conquistados por suas equipes ainda são enaltecidos nas conversas cotidianas na atualidade. Como afirmou o depoente Luis Pinto, a promoção do esporte contribuiu para que se desenvolvesse entre os membros das comunidades formadas no entorno das unidades produtivas um sentimento de pertencimento à Bata:

A Bata tinha o objetivo primeiro de dar bem-estar às pessoas. [...] E o outro era o esporte. Esporte, esporte, esporte. Era de tal forma que as pessoas tivessem um sentimento de pertencimento. "- Eu trabalho na Bata, jogo pela equipe de basquete da Bata." Ou pela equipe de futebol da Bata, ou pelo ciclismo da Bata, ou o hóquei da Bata ou o que fosse. Então as pessoas se sentiam identificadas com a companhia. ${ }^{105}$

\section{E assim como canções foram compostas para os alunos das escolas industriais entoarem} nas solenidades, as equipes esportivas da empresa tiveram seus cantos. Em uma das cenas mais marcantes da minha experiência como pesquisador, um "batino", que gentilmente me recebeu em sua casa, levantou-se da cadeira enquanto conversávamos informalmente e simulou marchar enquanto cantava o hino da equipe de futebol, repetindo os gestos que realizou ao longo da juventude, quando se dirigia com o pai ao estádio de futebol para torcer pela Bata. Os depoentes Patrício Zunica e Mauricio Ovalle ${ }^{106}$ descreveram o que define um "batino":

Zunica: Nós sempre falávamos: Somos batinos! Somos da família Bata! [...]

Ovalle: Eu sou batino! [...]

Zunica: Ser batino significava que você trabalha na Companhia Bata e se sentia parte da companhia. Não um mero trabalhador da companhia. Era uma parte da companhia.

Ovalle: Eu me sentia batino, me sinto batino. [...] Primeiro era o sistema econômico. Saíamos de férias e havia festas, como o quê! Festas no 18! [Festas Pátrias] A empresa te emprestava dinheiro. Havia muita ajuda, para os esportes, para as escolas... Esse coração batino vem também porque muitas gerações... como eu e Patrício, somos filhos de batinos que chegaram para trabalhar na Bata sem saber ler e escrever e Bata lhes deu estudo. Bata Ihes deu casa, calçado...

Zunica: Eu sou filho e neto e bisneto, bisneto. Meu bisavô trabalhou com o fundador em Zlín quando era oficina, não quando era fábrica. [...]

105 Depoimento de Luis Pinto Jeria ao autor. (grifos meus)

106 Patrício Zunica é filho de imigrantes checos e fez parte da quarta geração da família que trabalhou na Bata, enquanto Mauricio Ovalle é filho de ex-trabalhadores da empresa, sendo seu pai demitido e obrigado a se exilar, após o golpe militar de 1973, por conta da militância política. Ambos começaram a trabalhar nas fábricas de Peñaflor ainda jovens e chegaram a ocupar cargos de gestão no setor produtivo. Foram demitidos em meio ao processo de reestruturação que resultou no encerramento das atividades produtivas no Chile. Vivem em Peñaflor e atuam profissionalmente no setor calçadista: Zunica como consultor e Ovalle como gestor. 
Zunica: A Bata se preocupou muito em dar uma boa condição de vida a todas as pessoas. E a maioria dentro da fábrica tinha sido camponês e o camponês não sabe o que é sábado, domingo, descanso, férias. O camponês no Chile era muito mal pago. [...] Então ser batino era um orgulho e você cuidava do seu trabalho. Você cuidava do seu trabalho! E era uma vergonha se alguém era demitido da Companhia por roubar. Era uma vergonha para ele e para sua família. ${ }^{107}$

Portanto, o sentimento de pertencimento à companhia resultou de uma conjunção de fatores: muitos operários iniciaram suas vidas laborais no campo e viveram inúmeras privações antes de ingressarem na Bata; a empresa construiu um clube social e esportivo muito bem estruturado em Peñaflor, que se tornou o principal espaço de lazer da comunidade; pagava regularmente os salários, cumpria as garantias legais e ofertava vários outros benefícios. Tudo isso possibilitou que aquelas pessoas vivessem em melhores condições materiais do que viviam antes. Mesmo um depoente saudosista como Maurício Ovalle afirmou ter cumprido sua parte na relação ao se dedicar ao trabalho, mas destacou que outras empresas não ofereceram o mesmo tipo de retorno aos trabalhadores. "Tudo o que eu conquistei, eu mereci. Porque eu trabalhei. Nada é grátis. Mas eu também tenho consciência de que tenho amigos que trabalharam em outras empresas e fizeram o mesmo que eu e não se saíram bem."108 Constata-se ainda que o sentimento de pertencimento foi construído a partir da combinação dos ganhos materiais com o eficiente sistema de controle social, que teve nas famílias e na própria comunidade complementos de grande importância para disciplinar a força de trabalho, pois vir a ser demitido por conta de algum desvio de conduta era uma grande vergonha para todo o núcleo familiar. ${ }^{109}$

O último tema a ser analisado refere-se ao estímulo à composição de um quadro de funcionários estável e à valorização de quem labutava muitos anos na companhia. Conforme relatou Patrício Zunica, ele era parte da quarta geração de familiares que trabalharam na Bata, o que refletia o ideal da empresa de formar uma "família batina". A organização estimulava que os "bons" trabalhadores permanecessem na empresa ao longo de toda a vida produtiva e que seus descendentes seguissem a mesma trajetória. Em complemento, afirmava a possibilidade da ascensão hierárquica para quem se dedicava e era leal. Vendia o sonho de que, além de todos os benefícios, a lealdade seria recompensada por uma trajetória profissional ascendente. Aqueles que dedicaram décadas de suas vidas à Bata foram regularmente homenageados nas festas de premiação por 10, 15 e 20 anos de trabalho realizadas para os funcionários das unidades produtivas, bem como para os vendedores da cadeia de lojas no Chile. Nessas ocasiões, ao discursarem, os gestores ratificavam os ideais da harmonia social e da colaboração entre trabalhadores e capitalistas como baluartes da

107 Depoimentos de Maurício Ovalle e de Patrício Zunica ao autor. Peñaflor, 24 ago. 2018. (grifos meus) 108 Ibidem.

109 O estímulo à contratação de novos trabalhadores que possuíam parentesco com funcionários já estabelecidos foi uma estratégia recorrente de empresas paternalistas, pois favorecia o "enraizamento" e a vigilância por parte dos próprios familiares. Cf., entre outros, VENEGAS VALDEBENITO; MORALES BARRIENTOS, op. cit. 
prosperidade coletiva. Tal união de forças sustentava-se em papéis bem demarcados: os trabalhadores deveriam ser leais, disciplinados e altamente produtivos; em troca desfrutariam do bem-estar proporcionado pela produção sabiamente coordenada pelos fiéis discípulos de Tomas Bata, que punham em prática os ensinamentos recebidos nas escolas industriais e difundiam globalmente seu sistema totalitário de gestão e de controle cultural, ideológico, político e social.

\section{Considerações finais}

CONFORME DEMONSTREI ao longo do texto, as publicações da empresa utilizaram deliberadamente as imagens dos industriais da família Bata nos dois países. No Brasil, Jan Bata esteve constantemente presente no cotidiano da comunidade fabril. No Chile, onde os gestores exerceram majoritariamente a função de representar publicamente a empresa, as visitas de Thomas Bata causaram grande euforia e obras como a construção do Liceu de Peñaflor foram creditadas à sua generosidade pessoal. Em acréscimo, destaco que a imagem do fundador Tomas Bata também foi usada amiúde pelas publicações da empresa. As edições dos meses de julho do Novidades de Batatuba, do Bata Noticias e da Bata Noticias Chile publicaram regularmente homenagens à memória do fundador, que faleceu em 12 de julho de 1932. Um dos textos mais emblemático foi publicado em 1959:

Quis o Criador Supremo provar a qualidade de sua obra e o tirou do mundo
dos seres vivos e o enviou à região do descanso eterno. Mas de Tomas Bata,
como do Humilde Nazareno se pode dizer: "Passou fazendo o bem." Passou
pela vida tratando de melhorar a condição humana. Para eles fundou sua
Organização. [...] Deu em vida trabalho e bem-estar aos seus concidadãos
e quando o fantasma da guerra e da fome açoitou as cidades e campos da
velha Europa, buscou novos horizontes onde abrir os sulcos para semear a
semente do bem-estar comum. [...] Hoje, há 27 anos de sua morte, o recordamos com o mesmo carinho do filho para com seu pai..$^{110}$

Alguns anos antes fora inaugurado no hall de entrada do C.I.B. um busto de bronze do "querido Gigante da lendária Morávia" para irradiar "a luz da imortalidade" e servir como "um farol simbólico que guia a juventude pelo caminho do Trabalho e do Dever". ${ }^{111}$

Portanto, as evidências analisadas possibilitam concluir que a implantação do sistema Bata no Brasil e no Chile reproduziu características tanto do paternalismo industrial quanto do capitalismo de bem-estar, visto que o projeto almejava formar comunidades operárias leais às empresas, disciplinadas e regidas pelo ideal de paz social e de harmonia entre trabalhadores e capitalistas. Para tanto, utilizou desde a perpetuação da imagem do fundador da organização, por diversas vezes definido como um pai, até a montagem de aparatos assistenciais que,

110 Bata Noticias. IN MEMORIAM. a. V, n. 95, 11 jul. 1959. (tradução e grifos meus)

111 Idem. RECORDANDO AL FUNDADOR. a. III, n. 42, 18 jul. 1956. (tradução minha) 
se não atingiram as mesmas dimensões daquele montado na Checoslováquia, não foram desprezíveis, em especial no Chile. Assim, paternalismo industrial e capitalismo de bem-estar demonstraram ser conceitos úteis para interpretar o projeto de controle social da Bata.

Não obstante, demonstrei que o sistema Bata foi além dos objetivos de diminuir conflitos, de melhorar a moral dos trabalhadores e de cultivar a lealdade. A difusão do conjunto de métodos de produção, das técnicas de gestão da força de trabalho e, em especial, do projeto de controle social almejou alcançar um domínio total dos trabalhadores e de seus familiares. Para isso, não se limitou a aplicar técnicas e tecnologias destinadas a intensificar a produtividade por meio de um controle mais eficiente do tempo de trabalho e a oferecer benefícios sociais com a finalidade de fixar a força de trabalho e de minimizar focos de descontentamento. A empresa adentrou os espaços privados das vidas dos trabalhadores e buscou controlar os seus tempos de ócio, numa nítida demonstração de sistemática interferência no processo de produção e de reprodução da força de trabalho.

Outro aspecto relevante a se destacar refere-se à circulação de ideias a respeito das ações de controle social, disciplinamento e minimização de conflitos de classes. Conforme apontei, as visitas de Tomas Bata aos Estados Unidos serviram como fontes de inspiração tanto para as transformações dos processos produtivos de calçados quanto para a montagem de um amplo aparato assistencial na Checoslováquia. Portanto, o totalitarismo empresarial compôs um processo global de compartilhamento, adaptação, aprimoramento e difusão de estratégias de dominação e de promoção da harmonia social, implementadas em diferentes segmentos produtivos ao longo do século XX.

O fato de a Bata ser uma multinacional contribuiu para o aperfeiçoamento tanto dos métodos produtivos quanto do projeto de domínio total, que idealmente fora concebido para ser replicado transnacionalmente. Nesse sentido, o depoente Luis Pinto relatou que quando conheceu e atuou como gestor em outras unidades produtivas de diferentes países constatou que eram todas iguais: mesmo tipo de construção, de prédio, de máquinas, de material, de designação das oficinas pelos mesmos números, de reuniões, de mesas de escritório, de documentos etc. ${ }^{112}$ Os técnicos seguiam o mesmo manual, formulado para difundir o sistema Bata para qualquer localidade.

Não por acaso, constatei a reprodução no Brasil e no Chile de um mesmo padrão discursivo nas publicações oficiais da empresa, que enfatizavam exaustivamente os seguintes ideais: servir aos clientes por meio da fabricação de calçados de qualidade e com preços competitivos para proporcionar o aumento do mercado consumidor; incorporar constantemente novas tecnologias e novas técnicas para obter o aumento da produtividade; oferecer cursos de capacitação, em especial aos gestores, com o fim de estimular não apenas a adoção de modernas técnicas de gestão, mas também difundir estratégias para se se antecipar ou para minimizar os conflitos cotidianos por meio do que se convencionou chamar Relações

$\overline{112 \text { Depoimento }}$ de Luis Pinto Jeria ao autor. 
Humanas de Trabalho; e proporcionar bem-estar para os trabalhadores e seus familiares em troca da plena colaboração.

Para conquistar a lealdade de seus funcionários e estimular o sentimento de pertencimento à organização, fez-se uso da assistência social aos trabalhadores e do discurso de que a dedicação ao trabalho era o ponto determinante para a prosperidade da companhia e para o desenvolvimento pessoal, das comunidades, das cidades e dos países. Minha hipótese é que as "campanhas anti-Bata" dos anos 1920 e 1930 estimularam a empresa a se precaver para não entrar em rota de colisão com os governos nacionais e com o possível patriotismo de seus funcionários. Não por acaso, promoveu e patrocinou festas de comemoração das independências nacionais, da Proclamação da República etc.; publicou símbolos e textos sobre heróis nacionais; associou sua imagem aos interesses do Brasil e do Chile; e enfatizou que os estrangeiros "pioneiros" adquiriram a cidadania nos países em que atuavam e se tornaram importantes membros das comunidades locais.

As famílias operárias foram concebidas como o esteio do domínio total, pois a organização propagava que um lar saudável, bem administrado e feliz sustentava todo o resto. Em adição, patrocinou e estimulou a prática de esportes, os entretenimentos ditos "sãos", o combate ao alcoolismo, o cuidado adequado das crianças e assim por diante. Para fortalecer o sentimento de pertencimento utilizou as equipes esportivas, associando habilmente a paixão pelo esporte às cores da camisa da Bata, vestida por seus atletas como uma "segunda pele". Tudo isso compôs um universo totalitário de disciplinamento, condicionamento psicológico e controle dos tempos de trabalho e de ócio que objetivava conformar um trabalhador totalmente leal à Bata, designado inclusive por termos que reforçavam o ideal de ser parte de uma "família industrial" multinacional: "batador" e "batino".

Ou seja, não era apenas uma relação formal de compra e venda de tempo de trabalho, ia muito além, ao estimular a construção de uma identidade comum de interesses entre trabalho e capital por meio da propagação de comunidades fabris que viviam em torno da fabricação de calçados e de seus componentes. Dessa forma, sentir-se parte da companhia representava compor uma coletividade transnacional, construída pouco a pouco a partir dos ideais do fundador Tomas Bata, seguidos e aprimorados por seus herdeiros, por familiares e pelos executivos que deram concretude ao sistema originalmente formulado na Checoslováquia. Todavia, o exercício do domínio total não se fez sem ter de lidar com variadas expressões de questionamentos, de descontentamento e de resistência operária.

Recebido em 27/03/2020

Aprovado em 14/05/2020 